\title{
Innowacyjne rozwiązania finansowe dla inteligentnego rozwoju miast
}

\section{Krzysztof Waśniewski, Miron Maicki}

\section{STRESZCZENIE}

Niniejszy artykuł przedstawia wyniki badań nad zmianami społeczno-ekonomicznymi w polskich miastach w kontekście wyzwań związanych ze zmianami technologicznymi. Metody klasycznej analizy ekonometrycznej połączono w artykule z zastosowaniem sieci neuronalnej dla zidentyfikowania prawidłowości rozwojowych w siedmiu dużych polskich miastach: Warszawie, Krakowie, Poznaniu, Wrocławiu, Gdańsku, Łodzi i Kielcach. Wykonane badania dostarczają mieszanych przesłanek na temat tendencji na przyszłość, zwłaszcza w zakresie demografii. Pewne są jednak dwa zjawiska: wzrost skłonności do zakładania nowych przedsiębiorstw oraz spadek udziału wydatków inwestycyjnych w budżetach miejskich. Symulacja za pomocą sieci neuronalnej wskazuje na możliwość szybkiej eksplozji demograficznej badanych miast, mimo obecnej stagnacji, oraz możliwość dalszego, znacznego wzmocnienia zachowań przedsiębiorczych. W konkluzji artykułu omawiany jest zarys rozwiązania finansowego wykorzystującego zaobserwowane tendencje. Rozwiązanie to łączy elementy funduszu inwestycyjnego z crowdfundingiem (finansowanie społecznościowe) $)^{1}$.

Słowa kluczowe: polskie miasta, zmiany społeczno-ekonomiczne, klasyczna analiza ekonomiczna, sieć neuronalna, finansowanie społecznościowe (crowdfunding)

\section{Wstęp}

Jesteśmy coraz bardziej zurbanizowani jako cywilizacja, jednak w Polsce odsetek ludności w miastach powoli maleje, z 61,3\% w 1990 r. do 60,1\% w 2017. Biorąc pod uwage zmiany całkowitej liczby ludności w Polsce w tym samym okresie, tj. z 38110782 osób w 1990 r. do 37975841 osób w 2017, populacja ludności miejskiej w Polsce skurczyła się o prawie 540000 osób na przestrzeni niecałych trzech dekad. W tym samym okresie 1990-2017, odsetek ludności miejskiej w populacji świata wzrósł z 43\% do 54,8\%. Dzieje się to przy stałej powierzchni terenów miejskich w Polsce, wynoszącej ok. $30501,3418 \mathrm{~km}^{2}$. W historii swojego rozwoju miasta mają okresy prosperity oraz kryzysy. W długim okresie sukces rozwojowy miast zależy od wykorzystania szans pojawiających się w otoczeniu. Miasta, które tego nie potrafią, najczęściej są marginalizowane w długim okresie [Braudel 1985].

Wspólnoty samorządowe, w tym szczególnie miasta, stają się obecnie aktywnymi graczami zmian technologicznych. Połączenie stosunkowo dużej gęstości zaludnienia ze znaczącą koncentracją kapitału w jednym miejscu tworzą swoiste środowisko, zwane czasem

\footnotetext{
1 "Crowdfunding to rodzaj gromadzenia i alokacji kapitału przekazywanego na rzecz rozwoju określonego przedsięwzięcia w zamian za określone świadczenie zwrotne, który angażuje szerokie grono dawców kapitału, charakteryzuje się wykorzystaniem technologii teleinformatycznych oraz niższą barierą wejścia i lepszymi warunkami transakcyjnymi, niż ogólnodostępne na rynku", K. Król, Definicje crowdfundingu. crowdfunding.pl, 2011-11-25, [dostęp 13.04.2019].
} 
ekosystemem innowacyjnym. Niektórzy badacze wskazują nawet, że rozwój samorządów lokalnych - zwłaszcza - jako aktywnych graczy ekonomicznych i technologicznych jest istotnym czynnikiem stabilizującym systemy demokratyczne [Isufaj 2014]. Duże miasta są jednymi z najbardziej złożonych struktur społeczno-ekonomicznych stworzonych przez człowieka. Wewnątrz tych struktur można zaobserwować specyficzną mieszankę konkurencji i współpracy [Koszel, Bartkowiak 2017]. Miasta wydają się przechodzić przez długofalowe cykle oscylacji pomiędzy epizodami szybkiej ekspansji przy słabej zdolności do zrównoważonego rozwoju zjednej strony, a okresami zrównoważonego rozwoju połączonego ze względną homeostazą populacji i powierzchni [El Ghorab, Shalaby 2016]. Intuicyjnie można odróżnić miasta odnotowujące systematyczny wzrost demograficzny i ekonomiczny od tych bardziej stacjonarnych. Stosunkowo najwięcej miast jednocześnie bardzo dużych i szybko rosnących znajduje się w krajach rozwijających się oraz na niektórych rynkach wschodzących. Szybki wzrost tych aglomeracji wiąże się z systematycznie występującą bieda, niedożywieniem, dysfunkcją całych dzielnic w sprawach tak elementarnych jak gospodarka wodą i ściekami czy też bezpieczeństwo przeciwpożarowe [Szymańska, Korolko 2015]. Miasta stoją przed obiektywnymi wyzwaniami rozwojowymi oraz przed obiektywną koniecznością tworzenia odpowiednich strategii działania. Te ostatnie stają się obiektywną koniecznością, a nie kwestią swobodnego wyboru [Witkowski, Kiba-Janiak 2014]. Strategia rozwoju miasta rodzi się niejako spontanicznie, jako efekt koniecznej współpracy pomiędzy różnymi partnerami społecznymi [Chand, Anumitra 2018].

Relacje instytucji samorządu terytorialnego z mieszkańcami danego terytorium można przedstawić w duchu teorii agencji. Mieszkańcy to zbiorowy pryncypał, zaś organy samorządu to zbiorowy agent. Jednym z podstawowych wyzwań w takiej sytuacji jest zapewnienie odpowiedzialnego zarządzania ze strony agenta. Zarządzanie za pomocą publicznie jawnego systemu zarządzania strategicznego może przyczynić się do rozwoju odpowiedzialnych strategii ze strony organów samorządu [patrz np.: Randa, Tangke 2015]. Taki system zarządzania wykształca się w kontekście idiosynkratycznych cech lokalnych systemów komunikacji społecznej. Społeczności o wysokiej skłonności do komunikacji są istotnie sprawniejsze (od tych słabiej komunikujących się) we wdrażaniu nowych rozwiązań instytucjonalnych. Ta wyższa sprawność wydaje się być związana z fundamentalnym zjawiskiem zbiorowego rozumienia priorytetów: społeczności nacechowane obfitą komunikacją wykazują większą skłonność do wyraźnego formułowania wspólnych wartości oraz konkretnych celów ukierunkowanych na ich urzeczywistnienie [Panya i in. 2018; Evansi in. 2019]. Wydaje się, że istnieje pewna graniczna pojemność informacyjna procesów komunikacji wewnątrz społeczności lokalnej. W praktyce oznacza to, że im bardziej złożona jest informacja do przekazania, w tym do upublicznienia, tym niższe jest prawdopodobieństwo, że cała ta informacja zostanie faktycznie odebrana (zrozumiana) przez jej adresatów [Ameen i in. 2015].

Strategia rozwoju miasta kryje w sobie swego rodzaju paradoks obserwatora: sam fakt wyraźnego komunikowania i publikacji określonych wskaźników rezultatu wpływa na działania mierzone tymi wskaźnikami. Zjawisko to można zaobserwować w zarządzaniu samorządami terytorialnymi. Chen i in. wykazuja że publikacja sprawozdań finansowych 
samorządów terytorialnych istotnie wpływa na ich dyscyplinę finansowa, w tym na koszt długu publicznego zaciąganego przez te samorządy [Chen i in. 2016]. Jednocześnie wydaje się, że organy samorządu terytorialnego są rzeczywiście transparentne w zakresie swoich finansów tylko wtedy, kiedy lokalne elity polityczne mają w tym konkretny interes albo kiedy są do takiej transparentności zmuszone przepisami prawa [Sedmihradská 2015].

Strategia rozwoju miasta trafia na podobny grunt instytucjonalny jak zastosowanie np. nowych metod rachunkowości budżetowej. Dla danego zestawu miar rezultatu, potrzebne są adekwatne umiejętności pracowników organów samorządowych oraz ich partnerów społecznych w zakresie klasyfikacji zdarzeń do odpowiednich kategorii, raportowania i analizy. Jednocześnie, zastosowanie nowego zestawu miar pozwala zmienić punkt widzenia na zdolność samorządów do osiągania celów związanych z tymi miarami, a w konsekwencji może pomóc wykształcić i wzmocnić tę zdolność [Fuentes, Borreguero 2018]. Można stworzyć stosunkowo powtarzalną strukturę logiczną dla systemu zarządzania strategicznego na poziomie samorządu lokalnego, jednak badania empiryczne wskazuja, że konkretne zbiory wartości tych miar - czyli konkretne cele i lokalne strategie - są wysoce idiosynkratyczne, nawet w obrębie tego samego kraju [Garde 2009; Juhola 2018].

Niezależnie od tego, jak złożone są strategie wspólnot lokalnych, zwiększanie sprawności instytucjonalnej samorządów wymaga, prędzej czy później, porównania różnych miast, gmin czy regionów oraz określenia, które z nich mogą stanowić wzorzec rozwojowy. Mamy tu do czynienia z poważnym wyzwaniem metodologicznym: wspólnoty lokalne są idiosynkratyczne. Jednakowoż, wielość zmiennych można zredukować dzięki wzajemnej korelacji poszczególnych cech. Akande i in. [2019] proponują zestaw wyodrębnionych $\mathrm{w}$ ten sposób kryteriów dla rankingu europejskich miast pod względem zdolności do zrównoważonego rozwoju. Obejmuje on:

a) liczbę zgłoszeń patentowych do Europejskiego Urzędu Patentowego w przeliczeniu na milion mieszkańców wspólnoty lokalnej;

b) odsetek osób zatrudnionych w przedziale wiekowym 20-64 lata;

c) względne znaczenie handlu elektronicznego w lokalnej gospodarce;

d) łączną długość ścieżek rowerowych w km;

e) liczbę dni w roku, kiedy koncentracja pyłu zawieszonego PM10 w powietrzu przekracza $50 \mu \mathrm{g} / \mathrm{m}^{3}$;

f) emisję gazów cieplarnianych ze środków transportu, w milionach ton;

g) odsetek ścieków miejskich poddany oczyszczaniu;

h) odsetek gospodarstw domowych uskarżających się na hałas w otoczeniu mieszkalnym;

i) odsetek powierzchni miasta stanowiący tereny chronione;

j) odsetek energii elektrycznej generowany ze źródeł odnawialnych;

k) wskaźnik śmiertelności;

l) liczbę teatrów;

ł) zróżnicowanie wynagrodzeń w zależności od płci;

m) frekwencję wyborczą w wyborach do parlamentu europejskiego;

n) współczynnik Giniego w rozkładzie dochodu rozporządzalnego. 
Ranking oparty na tej metodologii pokazuje spore różnice. Berlin, na pierwszym miejscu, ma dziesięciokrotnie większą zdolność do zrównoważonego rozwoju niż Warszawa, znajdująca się na miejscu dwudziestym.

Mauher i Obersnel [2007] zaproponowali wielokryterialny system zarządzania dla miasta Rijeki, oparty na źródłowej koncepcji Strategicznej Karty Wyników, autorstwa Kaplana i Nortona. Nieco inaczej sformułowano tu obszary zarządzania, a mianowicie: rozwój społeczeństwa opartego na wiedzy, zrównoważony rozwój, integracja społeczeństwa opartego na wiedzy ze zrównoważonym rozwojem, projekty rozwojowe. Z kolei Staš i in. [2015] przedstawiają strategię rozwoju dla systemu ,zielonego transportu” w miastach, opierając się dosłownie na źródłowym modelu Strategicznej Karty Wyników, czyli na obszarach zdefiniowanych jako: finanse, relacje z klientami, procesy wewnętrzne, uczenie się i rozwój. Rahman i Chin rozwijają podobny model zarządzania systemem transportu miejskiego, w odniesieniu do Singapuru [Rahman, Chin 2013]. Wydaje się, że transport i jego infrastruktura są jednym z najbardziej oczywistych zastosowań typowych narzędzi zarządzania strategicznego w zarządzaniu miastami i aglomeracjami. Może to wynikać z faktu, że systemy transportu mają jednocześnie cechy wieloprzemysłowe pod względem skali i cechy sieciowe pod względem złożoności interakcji. Jednym z aspektów sieciowych jest konieczność współpracy z mieszkańcami przy tworzeniu inteligentnego systemu transportowego [Tomaszewska 2015; Sałabun, Kaczmarczyk 2018].

W literaturze są również obecne badania, w których efekty zarządzania miastem traktuje się w kategoriach zwrotu z inwestycji, a więc gdzie zakłada się przełożenie de facto wielokryterialnego systemu zarządzania na jedną zagregowaną miarę rezultatu. W tym samym nurcie zwraca się uwagę na strategiczne znaczenie marketingu miasta wobec interesariuszy [Goovaerts i in. 2014].

Miasta zaczynają dzisiaj odgrywać podobną rolę jak w starożytności, tj. zaczynają być znaczącymi, zorganizowanymi graczami ekonomicznymi i politycznymi. Dopasowują się do swojego otoczenia, ale jednocześnie narzucają temu otoczeniu określony kierunek inwestycji [patrz np. Jankowska 2015]. W tym procesie wybijania się miast do roli aktywnych graczy ekonomicznych jednym z kluczowych czynników wydaje się gęstość zaludnienia. Wysoka złożoność interakcji społecznych na obszarach gęsto zaludnionych tworzy unikatowe możliwości zwrotu z inwestycji w zaawansowane technologie, zwłaszcza technologie cyfrowe [Dyr 2015; Kumar 2016]. Wysoka gęstość zaludnienia tworzy specyficzne warunki, typowe dla Schumpeterowskiego cyklu twórczej destrukcji: z jednej strony miasta borykają się ze zjawiskiem kongestii, czyli zatłoczenia, a z drugiej strony sama kongestia stwarza unikatowe warunki dla komercjalizacji nowych rozwiązań [Nowicka 2014; Sitzia, Zheng 2018]. Względną gęstość zaludnienia, a w konsekwencji także stopień kongestii społeczności lokalnych, można oceniać nie tylko w odniesieniu do powierzchni terytorium, ale także w relacji do dostępnych zasobów żywności oraz źródeł energii [Waśniewski 2017a].

Zmiana technologiczna jest zjawiskiem turbulentnym i raczej nieliniowym [Toynbee 1946; Edgerton 2011], przy czym na przestrzeni ostatnich siedmiu dekad można zauważyć coraz szybsze tempo starzenia się technologii oraz towarzyszące mu zjawisko narastającej podaży pieniądza w relacji do PKB [Waśniewski 2017b]. 
Strategia tworzy się jako interakcja między jednostkami oraz między grupami społecznymi. W naukach o zarządzaniu oraz w ekonomii zwykło się przyjmować, że interakcje społeczne rozgrywają się $\mathrm{w}$ dwóch typach struktur: sieciach wymiany oraz hierarchiach przywództwa. Warto zwrócić uwagę na być może nieco zapomnianą kontrowersję wokół tej wizji teoretycznej. Klasyczna ekonomia zakłada, że sieci wymiany tworzą się jako pierwsze, a dopiero później na ich bazie tworzą się struktury hierarchiczne [Smith 1776; Parsons i in. 1965; Braudel 1992]. Jednakowoż już na początku dwudziestego wieku wyodrębnił się inny pogląd, zgodnie z którym złożone struktury społeczne to najpierw i przede wszystkim hierarchie, a dopiero później sieci wymiany. Pogląd ten reprezentował już Max Weber [Weber 1922, 1978], a obecnie podejmowany jest na nowo w badaniach historycznych nad zjawiskiem tworzenia dużych struktur politycznych i gospodarczych [Turchin 2003].

Stosunkowo świeże badania nad neurofizjologią relacji społecznych dostarczają istotnych przesłanek do postawienia hipotezy, że na poziomie neurologicznym percepcja hierarchii społecznej jest pierwotna $\mathrm{w}$ stosunku do percepcji zależności sieciowych i możliwości wymiany [Zink i in. 2008; Kumaran i in. 2012]. Powstaje w ten sposób nowa perspektywa na budowanie strategii organizacji, w tym strategii rozwoju społeczności lokalnych. Świadome wykorzystanie i kształtowanie zależności hierarchicznych oraz ich percepcji przez członków organizacji może być ważniejszym niż dotychczas myślano czynnikiem tworzenia i wdrażania strategii. Przez ponad 3 dekady w naukach o zarządzaniu mocno akcentowana była teza, iż dla większej sprawności organizacji należy spłaszczać piramidy hierarchiczne [Drucker 1986, 2012]. Możliwe jest jednak, że tzw. spłaszczanie hierarchii jest iluzją: likwidujemy formalną ekspresję zależności hierarchicznych, jednak samo zjawisko hierarchii pozostaje tak samo żywe i ważne. Wielokryterialna, strategiczna karta wyników dla organizacji może obejmować explicite wykorzystanie mechanizmów budowania hierarchii.

Inny nurt badań neurofizjologicznych poświęconych percepcji relacji społecznych wskazuje na mocniejszy niż dotychczas sądzono związek pomiędzy postrzeganiem znaczenia i języka, a podstawowymi funkcjami poznawczymi, takimi jak percepcja czasu i przestrzeni. W świetle tych badań język i jego struktura logiczna wydają się odzwierciedlać i jednocześnie kształtować fundamentalne odniesienia każdego z nas wobec otaczającej rzeczywistości materialnej [Nikolić 2015; Pulvermüller 2013]. Na podstawie tych badań można z kolei postawić hipotezę, że struktura logiczna strategii organizacji ma możliwość dosłownie zmieniać postrzeganie zupełnie podstawowych elementów codziennego działania.

Jednym z najważniejszych kierunków zmian w dzisiejszych miastach jest tworzenie struktur zwanych „inteligentnym miastem”, gdzie zaawansowane technologie stosowane są do głębokiej transformacji przestrzeni miejskiej. Inteligentne miasto jest kategorią ogólna, w ramach której występują różne strategie rozwoju: miasta oparte na wiedzy, miasta oparte na technologiach cyfrowych czy też miasta skupione na redukcji emisji gazów cieplarnianych. Kryterium wyodrębnienia tych strategii jest dominujący nurt aktywności ekonomicznej w mieście, chociażby obserwowalny jako charakterystyczny profil lokalnych startupów [patrz np. Stawasz i in. 2012]. Sikora-Fernandez [2013] proponuje klasyfikację obszarów zarządzania strategicznego miastem inteligentnym (czy też miastem aspirującym 
do tej kategorii). Autorka wyodrębnia sześć takich obszarów, które mogą być użyte w wielokryterialnej funkcji zarządzania strategicznego. Są to:

a) inteligentne systemy transportu;

b) rozwój zrównoważony;

c) kapitał społeczny;

d) współrządzenie;

e) jakość życia;

f) gospodarka oparta na wiedzy.

W dalszej części artykułu przedstawiane są badania nad inwestycjami samorządowymi oraz przedsiębiorczością w siedmiu dużych miastach Polski: Wrocławiu, Łodzi, Krakowie, Gdańsku, Kielcach, Poznaniu i Warszawie. Prezentowany jest również model finansowania inteligentnego rozwoju miast, oparty na uczeniu się poprzez eksperymentowanie. Podstawą teoretyczną tego podejścia sąbadania nad tzw. ogólną sztucznąinteligencją. Działanieludzkich społeczności można badać jako przejaw inteligencji zbiorowej. Najbardziej obiecującym kierunkiem teoretycznym w tym zakresie wydaje się tzw. teoria roju (swarmtheory), gdzie podstawowym przejawem zbiorowo inteligentnych zmian jest zdolność do zmiany stopnia sztywności stosunków społecznych [Stradner i in. 2013]. Algorytmy sztucznej inteligencji pozwalają symulować takie zbiorowo inteligentne zachowania przy zastosowaniu tzw. funkcji spójności (fitness function) [Sloman 1993; de Vincenzo i in. 2018]. Inteligencja to struktura logiczna zdolna tworzyć wiele lokalnych wersji samej siebie i uczyć się na drobnych błędach obserwowanych podczas działania tych lokalnych wersji. Inteligentny rozwój wspólnoty lokalnej to umiejętność eksperymentowania z przedsięwzięciami rozwojowymi tak, aby tworzyć sieć przedsięwzięć zdolnych dostarczać impuls rozwojowy, wykorzystując zarówno sukcesy, jak i porażki.

\section{Inwestycje samorządowe i startupy w dużych polskich miastach - analiza empiryczna zjawiska}

W dużych polskich miastach można zauważyć intrygujące zjawisko: budżety samorządowe stopniowo wycofują się z wydatków inwestycyjnych, a jednocześnie wzrasta liczba nowo uruchamianych podmiotów gospodarczych w przeliczeniu na 10 tys. mieszkańców. Tabela A.1. w Apendyksie A na końcu artykułu przedstawia dokładne dane liczbowe w tym zakresie. Dla siedmiu polskich miast - Wrocławia, Łodzi, Krakowa, Gdańska, Kielc, Poznania i Warszawy - pozyskano dane z Głównego Urzędu Statystycznego na temat wydatków samorządów tych miast oraz aktywności ekonomicznej społeczności lokalnych w zakresie tworzenia nowych podmiotów gospodarczych. W owych siedmiu miastach można zauważyć systematyczny spadek współczynnika udziału wydatków majątkowych inwestycyjnych w całości wydatków budżetów miejskich. W Warszawie, w 2008 r., współczynnik ten wynosił 19,8\%, w 2017 r. spadł do 12\%. W Krakowie, w analogicznym okresie 2008-2017, ten sam współczynnik spadł z 19,7\% do 11,5\%. Najbardziej spektakularne zmniejszenie tego współczynnika miało miejsce we Wrocławiu i Poznaniu, gdzie spadł on z ok. $30 \%$ do ok. $12 \%$. 
Równolegle do spadku udziału wydatków inwestycyjnych w budżetach badanych siedmiu miast, można tam zaobserwować przeciwny, rosnący trend w zakresie liczby nowo rejestrowanych podmiotów gospodarczych. Współczynnik liczby nowo zarejestrowanych podmiotów gospodarczych w przeliczeniu na 10000 mieszkańców, publikowany przez Główny Urząd Statystyczny, pokazuje na przestrzeni lat 2008-2017 wzrost o 72,5\% w Warszawie, o 43,2\% we Wrocławiu czy też o 28,5\% w Krakowie. Społeczności lokalne badanych siedmiu miast wykazują szybko rosnącą skłonność do tworzenia nowych podmiotów gospodarczych. Oczywiście, można by przyjąć pesymistyczne założenie, że obserwowane wzrosty to tylko efekt prekariatu, czyli rosnącej liczby miejsc pracy będących formalnie jednoosobową działalnością gospodarczą. Okazuje się jednak, że tak nie jest. W okresie 2008-2017, liczba osób fizycznych prowadzących działalność gospodarczą w Warszawie wzrosła jedynie o 10\%, podobnie we Wrocławiu.

Społeczności lokalne dużych miast zmieniają się na coraz bardziej przedsiębiorcze, a jednocześnie samorządy - a przynajmniej samorządy miejskie - wydają się powoli wycofywać $z$ bezpośredniego inwestowania w nowe zasoby trwałe. Mamy tu do czynienia ze zróżnicowaną korelacją. Tabela 1, poniżej, pokazuje wyniki analizy korelacji Pearsona między omawianymi zjawiskami. Wyliczono dwa współczynniki korelacji. Szereg czasowy współczynnika liczby nowych podmiotów gospodarczych na 10000 mieszkańców skorelowano z dwiema alternatywnymi miarami wydatków inwestycyjnych z budżetu miast: w kwocie bezwzględnej oraz jako udziału w wydatkach budżetowych ogółem. W większości przypadków ten drugi współczynnik korelacji jest jednoznacznie negatywny. Wyjątkami są Kielce i Łódź. W tych dwóch miastach trudno orzec o istotnej korelacji. Z kolei korelacja liczby nowych podmiotów gospodarczych z wartością bezwzględną wydatków inwestycyjnych z budżetu miasta jest wyraźnie idiosynkratyczna. Każde miasto wydaje się tu odrębnym przypadkiem.

Tabela 1. Wyniki analizy korelacji Pearsona

\begin{tabular}{|c|c|c|}
\hline Miasto & $\begin{array}{c}\text { Współczynnik korelacji „nowe podmioty } \\
\text { gospodarcze } \diamond \text { udział wydatków } \\
\text { inwestycyjnych w budżetach samorządów” }\end{array}$ & $\begin{array}{c}\text { Współczynnik korelacji „nowe podmioty } \\
\text { gospodarcze } \diamond \text { wartość bezwzględna } \\
\text { wydatków inwestycyjnych samorządów” }\end{array}$ \\
\hline Wrocław & $-0,92512283$ & $-0,865041414$ \\
\hline Łódź & $-0,225910379$ & 0,103059913 \\
\hline Kraków & $-0,677282879$ & $-0,19912138$ \\
\hline Gdańsk & $-0,678652072$ & $-0,415528966$ \\
\hline Kielce & 0,197095107 & 0,468779369 \\
\hline Poznań & $-0,668856617$ & $-0,439275309$ \\
\hline Warszawa & $-0,819121783$ & $-0,602553192$ \\
\hline
\end{tabular}

Źródło: opracowanie własne 
Analizę korelacji sformalizowano dalej w postaci analizy regresji liniowej metodą najmniejszych kwadratów. Współczynnik liczby nowo zarejestrowanych podmiotów gospodarczych na 10000 mieszkańców potraktowano jako zmienną objaśnianą (zależną). Zmiennym objaśniającymi są: a) kwota wydatków inwestycyjnych z budżetów miejskich, b) kwota całkowitych wydatków budżetów miejskich, c) liczba ludności miasta. W analizie regresji wykorzystano logarytmy naturalne danych z tabeli A.1. w Apendyksie A, jako panel danych (a więc poddano analizie siedem powtarzających się szeregów czasowych, po kolei dla każdego z siedmiu miast). Przyjęto, iż zmienna objaśniana może mieć wartość stałą rezydualną nieskorelowaną ze zmiennymi objaśniającymi. Wyniki analizy regresji podane są w tabeli 2, poniżej. Mamy do czynienia z dwiema silnymi, istotnymi zależnościami funkcjonalnymi. Im wyższe przeciętne wydatki z budżetu miejskiego ogółem, tym większa skłonność lokalnej społeczności do tworzenia nowych biznesów. Im większa liczba ludności, tym niższa jest ta skłonność. Ten konkretny związek funkcjonalny jest o tyle interesujący, że badane społeczności lokalne są mniej więcej stacjonarne pod względem demograficznym, a zmiany wartości zmiennej „ludność” biorą się przede wszystkim z różnic przestrzennych w źródłowym zbiorze danych. Ściśle pojęte wydatki inwestycyjne samorządu wydają się mieć drugoplanowe znaczenie. Rezydualna wartość zmiennej objaśnianej jest ujemna i obarczona dużą dozą przypadkowości, jeżeli chodzi o istotność związku. Mamy więc do czynienia z jakimś marginesem badanego zjawiska, który wymyka się tak sformułowanej analizie regresji.

Tabela 2. Wyniki analizy regresji

\begin{tabular}{|c|c|c|c|}
\hline \multicolumn{4}{|c|}{$\begin{array}{c}\text { Zmienna objaśniana: ln (Liczba nowo zarejestrowanych podmiotów gospodarczych } \\
\text { na } 10000 \text { mieszkańców) } \\
\mathrm{R} 2=0,608 \\
\mathrm{~N}=70\end{array}$} \\
\hline Zmienna objaśniająca & $\begin{array}{c}\text { Współczynnik } \\
\text { regresji liniowej }\end{array}$ & $\begin{array}{c}\text { Błąd } \\
\text { standardowy }\end{array}$ & $\begin{array}{c}\text { Poziom istotności } \\
\text { w teście T Studenta }\end{array}$ \\
\hline Ln (Wydatki inwestycyjne samorządu) & $-0,093$ & 0,048 & 0,054 \\
\hline Ln (Wydatki samorządu ogółem) & 0,565 & 0,083 & 0,000 \\
\hline Ln (Ludność) & $-0,328$ & 0,09 & 0,000 \\
\hline Stała & $-0,741$ & 0,631 & 0,245 \\
\hline
\end{tabular}

Źródło: opracowanie własne

Lokalne społeczności w siedmiu badanych miastach są coraz bardziej przedsiębiorcze. Coś się zmienia we wzorcach zachowań ludzi. Ta zmiana wydaje się być związana $\mathrm{z}$ obserwowaną w lokalnych samorządach tendencją do systematycznego powiększania budżetów miejskich, przy jednoczesnym zmniejszaniu udziału wydatków inwestycyjnych w tych budżetach. Patrząc na tę zmianę z punktu widzenia klasycznej ekonomii, widzimy realokację kapitału. Gdyby miasto porównać do przedsiębiorcy, to badane miasta stają się coraz bardziej krótkowzroczne i coraz mniej nastawione na długofalowy rozwój: reinwestują coraz mniej. Sektor prywatny, z wyraźną tendencją do eksperymentowania poprzez większą 
liczbę nowo tworzonych biznesów na 10000 mieszkańców, wydaje się przejmować od samorządów pałeczkę inwestowania. Prawdopodobnie obie tendencje mają swoje racjonalne podstawy. Powstaje pytanie - w jaki sposób twórczo wykorzystać oba zjawiska w celu sprostania wyzwaniom rozwojowym, przed jakimi stoją duże miasta?

\section{Symulacja zmian w miastach za pomocą sieci neuronalnej}

Tendencje omówione w poprzednim rozdziale skłaniają do zastanowienia, w jakim kierunku zmierzają badane miasta. Jedną z możliwości zbadania tego kierunku jest zastosowanie sztucznej inteligencji: sieci neuronalnej naśladującej inteligencję zbiorową. Na podstawie wyników analizy statystycznej, omówionych w poprzednim rozdziale, przeprowadzono symulację zmian w lokalnych gospodarkach miejskich, rozumianych jako inteligencje zbiorowe.

Obserwujemy ujemną korelację między współczynnikiem nowych firm na 10000 mieszkańców a wydatkami inwestycyjnymi samorządów, dodatnią korelację owego współczynnika z ogólnymi rozmiarami budżetów samorządowych oraz kolejną ujemną korelację z liczbą ludności. Jednocześnie w modelu ekonometrycznym mamy znaczącą ujemną wartość stała, której korelacja ze zmienną wyjaśnianą jest jednak nieistotna. Wyniki analizy regresji prowadzą do nieco absurdalnego scenariusza: gdyby ludność miasta malała asymptotycznie do zera, a wydatki samorządu rosły w kierunku nieskończoności, to częstość postaw przedsiębiorczych również rosłaby do nieskończoności. Jednocześnie częstość ta jest obciążona trudnym do jednoznacznego przewidzenia handicapem, swego rodzaju rezydualną awersją do przedsiębiorczości. Czy jest to po prostu absurdalna ekstrapolacja, czy też kryje się tu coś więcej?

Miasta, a szczególnie owych siedem dużych polskich miast poddanych analizie ekonometrycznej w poprzednim rozdziale, działają w skończonej przestrzeni. Zmiany liczby ludności są więc jednocześnie zmianami gęstości zaludnienia. Postawy przedsiębiorcze, mierzone współczynnikiem nowych firm na 10000 mieszkańców, mogą być ujemnie skorelowane nie tyle z liczbą ludności sensu stricto, ile z gęstością zaludnienia. Skądinąd znana jest zależność między gęstością zaludnienia a imperatywami inwestycyjnymi samorządu: większa gęstość zaludnienia rodzi większe zapotrzebowanie na infrastrukturę, a więc na nowe wydatki inwestycyjne. To właśnie gęstość zaludnienia może być zmienną pośredniczącą w zaobserwowanej, ujemnej korelacji między wydatkami inwestycyjnymi samorządów a współczynnikiem liczby nowych firm na 10000 mieszkańców.

Wyłania się wzorzec behawioralny mieszkańców dużych miast. Rozwijają postawy przedsiębiorcze w korelacji z wydatkami bieżącymi samorządów oraz z możliwym spadkiem gęstości zaludnienia, podczas gdy wydatki inwestycyjne samorządów oraz wzrost gęstości zaludnienia działają jak inhibitory postaw przedsiębiorczych. Zachowania przedsiębiorcze same w sobie - skłonność do zakładania nowych firm - są zjawiskiem korzystnym. Są przejawem aktywnego kształtowania przestrzeni społecznej, mogą być powiązane z aktywizmem społecznym i świadomym kształtowaniem instytucji. Powstaje pytanie: 
czy i pod jakimi warunkami społeczna energia tych zachowań może być wykorzystana w pozytywnym sprzężeniu zwrotnym z nakładami inwestycyjnymi samorządów? Czy da się „przesterować” życie dużych miast tak, aby zachowania przedsiębiorcze były w pozytywnej korelacji z tymi nakładami?

Nowoczesne technologie cyfrowe, w szczególności technologia Blockchain, umożliwiają nowe podejście do finansowania startupów, za pomocą tzw. kontraktów inteligentnych (ang. Smart contracts), których konstrukcja opiera się na podobnych rozwiązaniach jak te stosowane w kryptowalutach. Struktura logiczna klasycznej, kompleksowej umowy zostaje rozbita na drobne komponenty składowe, które są następnie łączone ze sobą nawzajem za pomocą hasz kodów tworzących łańcuch blokowy. O tym, jaką nową dynamikę dostają klasyczne kontrakty inwestycyjne dzięki temu nowemu podejściu świadczy rozwój platform crowdfundingowych, takich jak KickStarter, StartEngine czy też Polak Potrafi. Finansowanie społecznościowe przy zastosowaniu kontraktów inteligentnych powoduje szybkie pojawianie się zupełnie nowych rozwiązań instytucjonalnych, np. umów łączących kontrakty terminowe na dostawę produktów lub świadczenie usług z instrumentami pochodnymi od udziałów w spółce z ograniczoną odpowiedzialnością. Kontrakty inteligentne rozwijają się tak szybko, że tworzą de facto nowy porządek prawny w zakresie prawa prywatnego, poza klasycznym procesem legislacyjnym [patrz np.: Agrawal i in. 2014; Rupeika-Apoga, Danovi 2015; Savelyev 2017; Armour, Enriques 2018].

Praktyczne zastosowanie kontraktów inteligentnych, m.in. w postaci crowdfundingu, pozwala uświadomić sobie, jak szybko można tworzyć nowe rozwiązania instytucjonalne za pomocą technologii cyfrowych. Inwestycje samorządów dużych polskich miast można sprzęgnąć z zachowaniami przedsiębiorczymi mieszkańców za pośrednictwem funduszu inwestycyjnego opartego na technologii kontraktów inteligentnych, łączącego partnerstwo publiczno-prywatne z elementami crowdfundingu tak, aby lokalne startupy mogły znajdować finansowanie jednocześnie u lokalnej społeczności oraz w budżecie miasta. Zauważmy przy tym, że fundusz inwestycyjny może być traktowany jako możliwe rozwiązanie praktyczne, ale także jako konstrukcja teoretyczna. Zagregowany strumień nakładów inwestycyjnych można podzielić na odrębne, cząstkowe decyzje inwestycyjne i dla każdej z nich można określić uwarunkowania zwrotu z inwestycji. W ten sposób konstruujemy jedną z możliwych wersji polityki inwestycyjnej, opartą na racjonalności typowo biznesowej. Takie podejście jest cenne, kiedy mamy do czynienia z wielością możliwych celów.

Powstaje pytanie, w jakim kierunku może rozwijać się rzeczywiście istniejące i działające rozwiązanie tego typu w dużym mieście w Polsce? Wyobraźmy sobie społeczność działającą zgodnie z teorią roju [patrz: Stradner i in. 2013], jak inteligencja zbiorowa. Wydatki samorządów są czynnikiem systemowym - czymś w rodzaju feromonu - którego stężenie $\mathrm{w}$ przeliczeniu na jednego mieszkańca jest dodatnio skorelowane $\mathrm{z}$ występowaniem postaw przedsiębiorczych. W ramach tego czynnika systemowego mamy element składowy-wydatki inwestycyjne - który z kolei jest ujemnie skorelowany z postawami przedsiębiorczymi. To trochę tak, jakbyśmy w roju pszczół mieli feromon, który może występować w dwóch wersjach: ze znacznikiem chemicznym „wydatki inwestycyjne” albo bez tego znacznika. 
Niniejszy rozdział przedstawia symulację możliwych zmian w profilu typowego miasta oraz rozwoju takiego właśnie rozwiązania finansowego, jak naszkicowane powyżej, za pomocą sieci neuronalnej opisanej w Apendyksie B na końcu artykułu.

Sieć neuronalna jest co do zasady narzędziem optymalizacji. Sztuczną inteligencję można porównać do inteligencji robota, którego chcemy nauczyć wykonywania zadań przy jednoczesnym przystosowaniu do zmiennych warunków. Z logicznego punktu widzenia sieć neuronalna wykonuje podobne zadanie jak model stochastyczny przedstawiony w poprzednim rozdziale, jednak zamiast minimalizować odległość obliczanej funkcji wobec wszystkich empirycznych punktów danych jednocześnie (zasada najmniejszych kwadratów), eksperymentuje z każdym punktem danych po kolei, a następnie może eksperymentować z własnymi obliczeniami na danych empirycznych. Zastosowanie sieci neuronalnej pozwala sformułować stosunkowo spójne i dokładne hipotezy dla układów złożonych z wielu zmiennych, także wtedy, kiedy korelacje między tymi zmiennymi wydają się wzajemnie sprzeczne, jak w omawianym przypadku.

Celem symulacji było sformułowanie hipotez na temat tego, w jakim kierunku mogą zmieniać się miasta $\mathrm{w}$ obecności nowego rozwiązania finansowego ułatwiającego interakcję pomiędzy budżetem samorządu lokalnego a nowo powstającymi przedsiębiorstwami. Założono istnienie hipotetycznego funduszu inwestycyjnego, który selekcjonowałby 5\% najbardziej obiecujących przedsięwzięć spośród nowo rejestrowanych podmiotów gospodarczych i każdy z tych podmiotów dokapitalizowałby równowartością kwoty $€ 80$ 000, za pomocą odpowiednio dobranego koszyka rozwiązań finansowych. Kwota €80 000 została zaczerpnięta z badań prezentowanych przez portal Startup Hubs Europe. Liczbę takich podmiotów obliczono jako iloczyn liczby ludności w analizowanych siedmiu miastach, podzieloną przez 10000 oraz współczynnika liczby nowo rejestrowanych przedsiębiorstw na 10000 mieszkańców.

Dla każdego z badanych siedmiu miast wyliczono w ten sposób hipotetyczną wartość kapitału inwestowanego co rok przez samorząd lokalny w lokalne startupy. Dla danych prezentowanych $\mathrm{w}$ Apendyksie A obliczono ich średnie arytmetyczne z całego operatu badawczego. Średnie te potraktowano jako wartości oczekiwane dla hipotetycznego stanu wyjściowego, czy też miasta modelowego na potrzeby prezentowanego dalej eksperymentu. Są one następujące:

a) Liczba nowo zarejestrowanych podmiotów gospodarczych na 10000 mieszkańców -223;

b) Wydatki inwestycyjne samorządu - $759059742,89 \mathrm{zl}$;

c) Wydatki samorządu ogółem - 4281268 848,23 zł;

d) Ludność - 721083 ;

e) Zmienna hipotetyczna: inwestycja samorządu lokalnego w 5\% nowych przedsiębiorstw, równowartość €80 000 dla każdego - 373674 438,37 zł, czyli 8,7\% wydatków budżetu miasta.

Dane z Apendyksu A wykorzystano jako zbiór uczący dla sieci neuronalnej, której strukturę logiczną omówiono w Apendyksie B. Dane empiryczne z tabeli A.1, wyszczególnione powyżej jako (a) - (d), potraktowano jako zmienne wejściowe sieci neuronalnej (sygnał 
zewnętrzny). Zmienną hipotetyczną (e), wyliczoną na podstawie zmiennych (a) oraz (d), przyjęto za zmienną wynikową y sieci neuronalnej. Warto w tym miejscu wyjaśnić logikę wyodrębniania zmiennej wynikowej ze zbioru zmiennych empirycznych. W zastosowaniach sieci neuronalnych do optymalizacji, np. w robotyce, zmienna wynikowa jest pożądanym efektem działania urządzenia. Jednakowoż, kiedy stosujemy sieci neuronalne jako narzędzie poznawcze, zależy nam na sformułowaniu spójnych hipotez odnośnie do możliwego stanu rzeczy. Zależy nam na skonstruowaniu spójnych logicznie zestawień różnych możliwych stopni swobody zmiennych objętych badaniem. Kiedy jedną ze zmiennych wyodrębniamy jako zmienną wynikową sieci neuronalnej i kiedy sieć wykazuje zdolność minimalizacji błędu, dajemy tej zmiennej najmniej możliwych stopni swobody. Zmienna wynikowa podlega stosunkowo najmniejszym wahaniom w kolejnych rundach eksperymentalnych. Jest ona swego rodzaju kotwicą poznawczą sieci. Wokół tej stosunkowo stabilnej wartości sieć buduje różne scenariusze w stosunku do zmiennych wejściowych.

W zastosowaniach poznawczych sieci neuronalnej zmienna wynikowa jest więc ta, na której „najmniej nam zależy” z badawczego punktu widzenia. W ten sposób jest właśnie wyodrębniona zmienna (e), powyżej. Z poznawczego punktu widzenia jest to skorygowany wskaźnikiem 5\% i stałą €80 000 iloczyn oczekiwanych wartości średnich ze zmiennych: (d) liczby ludności oraz (a) liczby nowych podmiotów gospodarczych na 10000 mieszkańców. Jest to jedna z wielu możliwych lokalnych wartości, jakie można skonstruować na podstawie zbioru danych empirycznych przedstawionych w tabeli A.1. w Apendyksie A. Zdefiniowanie tej konkretnej wartości, jako zmiennej wynikowej sieci neuronalnej, jest więc swego rodzaju sztuczką logiczną: to trochę tak, jakbyśmy programowali sztuczną inteligencję robota magazynowego i wyznaczyli jego zmienną wynikową jako umiejętność postawienia paczki z towarem zawsze dokładnie w tym samym miejscu. Taka umiejętność u robota nie jest szczególnie cenna. Zależy nam raczej na tym, żeby umiał wybrać miejsce w magazynie w zależności od warunków. Kiedy jednak damy mu takie proste zadanie, możemy obserwować, jak zmienia się jego zachowanie w innych aspektach, w zależności od warunków zewnętrznych. Nasz „robot” w tej konkretnej sytuacji to zbiór danych z tabeli A.1. Chcemy sprawdzić, jakie możliwe zachowania może wykształcić nasz zbiór danych, jeżeli nakażemy mu uczyć się na błędach w wyznaczaniu tej konkretnej zmiennej (e).

Dane z tabeli A.1., po standaryzacji w przedziale $0<x i \leq 1$, względem lokalnych maksimów, wykorzystano jako zmienne uczące sieci w ten sposób, że w pierwszych 71 rundach eksperymentalnych sieć obliczała lokalny błąd $e$ w relacji do wartości zmiennej y obliczonej na podstawie rzeczywistej liczby ludności oraz rzeczywistego współczynnika liczby nowo rejestrowanych podmiotów gospodarczych na 10000 mieszkańców. Po tych 71 „rzeczywistych” rundach, sieć wykonała 5000 kolejnych rund eksperymentalnych wykorzystując wartości uzyskane w ostatniej, $\mathrm{t}=71$, rundzie opartej na danych rzeczywistych.

Przeprowadzono cztery eksperymenty, na podstawie czterech różnych wzorców selekcji sygnału wyjściowego. Eksperyment $\mathbf{1}$ polegał na systematycznej preferencji sygnału z funkcji sigmoidalnej przy biernej pamięci sieci, tzn. bez zjawiska redukcji dysonansu poznawczego rosnącej $\mathrm{w}$ miarę akumulacji danych. Zgodnie z równaniem 
(B.5) parametry $\beta 1$ oraz $\beta 2$ przyjmują odpowiednio wartości $\beta 1=1$ i $\beta 2=0$, a $f(t)=1$. Jest to eksperyment, w którym inteligencja zbiorowa reprezentowana przez sieć neuronalną preferuje wygaszanie wstrząsów zewnętrznych - trochę jakby była wyposażona w instytucje antycyklicznej polityki gospodarczej - jednak jej pamięć jest bierna w czasie. Eksperyment 2 preferuje sygnał z funkcji tangensa hiperbolicznego przy biernej pamięci, czyli według równania (B.5) $\beta 1=0$ i $\beta 2=1$, przy $f(t)=1$. W tym eksperymencie sieć neuronalna symuluje zachowanie takiej inteligencji zbiorowej, która mocno reaguje na wstrząsy zewnętrzne, np. jest pozbawiona antycyklicznych polityk gospodarczych. Eksperyment 3 zakłada, że neuron 4, czyli neuron selekcyjny sieci, oblicza średnią arytmetyczną z błędów zwracanych przez neurony 3.1. i 3.2. i zachowuje pamięć bierną. Parametry równania (B.5) są tu następujące: $\beta 1=0,5$ i $\beta 2=0,5$ oraz $f(t)=1$. Jeżeli błąd zwracany przez jeden z neuronów warstwy 3 jest systematycznie większy niż błąd z drugiego z nich, średni błąd propagowany przez wiele rund eksperymentalnych jest pod dominującym wpływem tego właśnie neuronu. Jest to swego rodzaju sztuczka matematyczna, która pozwala ująć licznik równania (B.5) w sposób de facto nieparametryczny.

Jako przedstawienie inteligencji zbiorowej, eksperyment 3 symuluje zachowania takiej społeczności, która co prawda posiada polityki redukujące wpływ wstrząsów zewnętrznych, jednak skuteczność tych polityk jest zmienna w czasie. Eksperyment 4 przyjmuje licznik błędu z równania (B.5) tak, jak w eksperymencie 3, jednak dodaje element redukcji dysonansu poznawczego, a więc pamięci systematycznie wygaszającej nowe informacje, dla minimalnego dysonansu w porównaniu z informacjami już posiadanymi. Formalnie oznacza to, że dla każdej rundy eksperymentalnej $t>1, f(t)=t-1$. W tym eksperymencie symulujemy zachowanie takiej inteligencji zbiorowej, która zaczyna się uczyć pod wpływem jakiegoś hipotetycznego „,wielkiego impulsu” w rundzie eksperymentalnej 1, a następnie jest coraz mniej chętna do uczenia się, w miarę upływu czasu od tego początkowego impulsu.

Zauważmy, że nasz poznawczy „robot” ma w sobie paradoks logiczny. Zmienna (e) jest zakotwiczona jako zmienna wynikowa, jednak jej dwa czynniki składowe - liczba ludności (d) oraz współczynnik liczby nowych firm na 10000 mieszkańców (a) - są „,wolne”, czyli sieć neuronalna może z nimi eksperymentować. W efekcie tych eksperymentów powstają dwie równoległe wartości. Jedną z nich jest zmienna wynikowa (e) $=5 \%$ * $€ 80000 * 4,3 *(a) *(d)$, a drugą jest jej hipotetyczny odpowiednik (e)', obliczony na podstawie eksperymentalnej kombinacji czynników (a)' oraz $(\mathrm{d})^{\prime}$, obliczonych przez sieć neuronalną a więc jako $(\mathrm{e})^{\prime}=5 \% * € 80000 * 4,3 *(\mathrm{a})^{\prime *}(\mathrm{~d})^{\prime}$.

W tabeli 3, poniżej, pokazano wyniki wszystkich czterech eksperymentów po 71 rundach uczących i 5000 rundach ściśle pojętego eksperymentowania przez sieć neuronalną. Zanim zostaną one dokładnie omówione, warto przedstawić zasady ich interpretacji. Zastosowana sieć neuronalna uczy się na drobnych, lokalnych zależnościach między zmiennymi i tworzy probabilistyczną projekcję tego, w jakim kierunku te zależności mogą pchać złożony układ podlegający badaniu. Predykcja za pomocą sieci neuronalnej ma podobny charakter jak stosowanie równań fizyki kwantowej w projektowaniu eksperymentów fizycznych: zamiast uśredniać obserwowane zależności - jak to ma miejsce w predykcji za pomocą 
modeli ekonometrycznych opartych na regresji wielorakiej - sieć neuronalna eksploruje te zależności, które w regresji widoczne są jako błąd standardowy.

Wartość poznawczą eksperymentów przeprowadzonych za pomocą sieci neuronalnej można oceniać stosując trzy kryteria. Pierwszym jest zdolność sieci do utrzymania wartości zmiennej wynikowej y tak blisko wartości początkowej-określonej powyżej w uśrednionych cechach miasta modelowego - jak to tylko możliwe. Jak można zaobserwować w tabeli 3, wszystkie cztery eksperymenty przyniosły praktycznie identyczną wartość zmiennej wynikowej y.

Pozostałe dwa kryteria oceny wartości poznawczej to: błąd estymacji zmiennej wynikowej generowany w poszczególnych rundach eksperymentu oraz średnia wartość funkcji spójności dla wszystkich zmiennych sieci, obliczana zgodnie z równaniem (B.1) w Apendyksie B. Zgodnie z cytowanymi wcześniej założeniami teoretycznymi [Stradner i in. 2013; Sloman 1993; de Vincenzo i in. 2018] sieć neuronalną uważa się za wiarygodną reprezentację inteligencji zbiorowej, jeżeli okazuje powtarzalny wzorzec zmian wartości swojej funkcji spójności, czyli kiedy okazuje zdolność do sukcesywnego rozluźniania i zacieśniania odległości Euklidesowej między zmiennymi. Obserwacja błędu generowanego przez sieć pozwala wyciągnąć wnioski na temat sposobu uczenia się $\mathrm{w}$ danych warunkach eksperymentu.

W Apendyksie C znajdują się wykresy przedstawiające zmiany wartości funkcji spójności sieci neuronalnej oraz generowanego przez nią błędu w czterech omówionych wcześniej eksperymentach. Wszystkie cztery eksperymenty wykazują istotne zmiany wewnętrznej spójności sieci, więc wszystkie cztery można uznać za wiarygodne odzwierciedlenie działania inteligencji zbiorowej. Stosunkowo „najśmielsza” sieć wydaje się być w eksperymencie 3: tam najbardziej rozluźnia swoją wewnętrzną spójność. Eksperyment 2 prowadzi do podobnego efektu, jednak na nieco mniejszą skalę. Eksperymenty 4 i 1 narzucają sieci nieco większą spójność - a więc teoretycznie mniej szans do nauczenia się czegoś nowego - a jednocześnie owa spójność ma skłonność do mocniejszej oscylacji. Obserwacja wykresów błędu pokazuje, że sposób uczenia się sieci w eksperymencie 1 jest istotnie odmienny od trzech pozostałych. W tym eksperymencie sieć wydaje się nie mieć zdolności długookresowej minimalizacji błędu. Układ inteligentny wyposażony w mechanizm systematycznego wygaszania wstrząsów zewnętrznych, przedstawiany przez funkcję sigmoidalna, wydaje się ciągle miotać między różnymi estymacjami zmiennej wynikowej, bez wyraźnego trendu redukcji.

Cztery różne eksperymenty i związane z nimi cztery różne procesy uczenia się pokazują jednocześnie wspólne prawidłowości oraz efekty idiosynkratyczne. Liczba ludności miejskiej w Polsce maleje i ludność siedmiu miast poddanych analizie za pomocą sieci neuronalnej wykazuje cechy stacjonarne z lekką skłonnością do spadku demograficznego. Tym niemniej, wszystkie cztery eksperymenty za pomocą sieci neuronalnej przyniosły predykcję znacznego wzrostu liczby ludności. Miasto modelowe, uśrednione z empirycznych danych wejściowych, ma 721 tys. mieszkańców. Najbardziej konserwatywny pod tym względem eksperyment 4 dał predykcję wzrostu tej liczby do ponad 3 milionów, zaś eksperymenty 1-3 przyniosły projekcję przewyższającą 7 milionów. Jest to efektem zestawienia danych empirycznych z miast o różnej liczbie ludności, przede wszystkim efektem zestawienia 
Warszawy z pozostałymi sześcioma miastami. Sieć neuronalna interpretuje tę różnicę jako wysokie prawdopodobieństwo, iż każde hipotetyczne miasto może mieć swój odpowiednik w postaci miasta większego od niego.

Jeżeli teraz przełożymy ten czysto logiczny wzorzec na realnie zachodzące procesy rozwojowe miast, możemy go interpretować jako teoretyczną możliwość, że każde hipotetyczne miasto może zacząć przejawiać mechanizmy wzrostu charakterystyczne dla metropolii, a więc zdolność do przyciągania znacznej liczby mieszkańców z innych miejscowości. Sieć neuronalna, przy podanych założeniach, symuluje mechanizm ekspansji ilościowej miast. Badane siedem miast wydaje się mieć potencjał w kierunku takowej ekspansji. W kontekście danych empirycznych z tabeli A.1. ten potencjał można interpretować jako wysokie prawdopodobieństwo konkurencji o pozycję metropolii. W układzie przestrzennym, gdzie jedna duża metropolia sąsiaduje, w ramach jednego kraju, z innymi dużymi miastami, te ostatnie mogą wejść na ścieżkę konkurowania z metropolią pod względem przyciągania mieszkańców i biznesu. Miasta te są wyeksponowane na zjawisko kongestii omówione we wprowadzeniu teoretycznym. Wysoce prawdopodobny jest scenariusz nasilonej migracji do tych miast, co z kolei zrodzi potrzebę nowego i nowoczesnego zaplecza technologicznego.

Wszystkie cztery eksperymenty przyniosły również predykcję znacznego rozwoju zachowań przedsiębiorczych, obserwowanych jako wzrost wartości współczynnika nowo rejestrowanych podmiotów gospodarczych. Znów najbardziej konserwatywny jest pod tym względem eksperyment 4, który pozwala oczekiwać wzrostu ponad 3-krotnego. Najdalej idący eksperyment 3 pozwala oczekiwać wzrostu prawie 8-krotnego. W tym punkcie warto zwrócić uwagę na podobieństwo między tymi konkretnymi wynikami eksperymentów sieci neuronalnej, a danymi empirycznymi. We wszystkich siedmiu badanych miastach nastąpił wzrost wartości współczynnika nowych podmiotów gospodarczych na 10000 mieszkańców. Przedstawiona wcześniej analiza regresji wskazuje na dodatnią korelację między tym współczynnikiem a liczbą ludności. Eksperymenty z zastosowaniem sieci neuronalnej pokazują jak dalece mogą zmienić się postawy przedsiębiorcze mieszkańców miast, które zaczną przejawiać metropolitalny wzorzec ekspansji.

W tabeli 3 przedstawione są dwie wartości zmiennej hipotetycznej zdefiniowanej na początku rozdziału, czyli wartości kapitału inwestowanego przez budżet miejski w 5\% nowo powstających firm. Wartość obliczona przez sieć neuronalną jest prawie identyczna z wartością początkową. Jej obserwacja służy raczej ocenie dokładności estymacji wykonanej przez sieć. W kolejnym wierszu tabeli 3 pokazana jest tzw. wartość przeliczeniowa tej zmiennej. Gdyby wziąć predykcję liczby ludności i predykcję liczby nowych firm na 10 000 mieszkańców, jednocześnie utrzymując założenie finansowania równowartością $€ 80000$ dla 5\% nowych firm, otrzymujemy wartości z tego ostatniego, najniższego wiersza tabeli 3. Najbardziej konserwatywny z czterech eksperyment 4 przewiduje wzrost zagregowanej kwoty inwestowanej w ten sposób do 15,3\% budżetu miasta jako całości, z 8,7\% przewidzianych w wyjściowych cechach miasta modelowego. Najśmielszy pod tym względem eksperyment 3 podnosi tę proporcję do $34,5 \%$. 
Tabela 3. Wartości zmiennej hipotetycznej

\begin{tabular}{|c|c|c|c|c|}
\hline Zmienna & $\begin{array}{c}\text { Eksperyment } \\
\mathbf{1}\end{array}$ & $\begin{array}{c}\text { Eksperyment } \\
\mathbf{2}\end{array}$ & $\begin{array}{c}\text { Eksperyment } \\
\mathbf{3}\end{array}$ & $\begin{array}{c}\text { Eksperyment } \\
\mathbf{4}\end{array}$ \\
\hline $\begin{array}{c}\text { Nowe podmioty gospodarcze } \\
\text { na 10 000 mieszkańców }\end{array}$ & 1310 & 1580 & 1724 & 759 \\
\hline Wydatki inwestycyjne samorządu & $10359 \mathrm{mln} \mathrm{zł}$ & $10153 \mathrm{mln} \mathrm{zł}$ & $11174 \mathrm{mln} \mathrm{zł}$ & $4321 \mathrm{mln} \mathrm{zł}$ \\
\hline Wydatki samorządu ogółem & $61024 \mathrm{mln} \mathrm{zł}$ & $60223 \mathrm{mln} \mathrm{zł}$ & $66259 \mathrm{mln} \mathrm{zł}$ & $25754 \mathrm{mln} \mathrm{zł}$ \\
\hline Ludność & 7000967 & 7008919 & 7706308 & 3026024 \\
\hline $\begin{array}{c}\text { Hipotetyczna wartość inwestycji } \\
\text { w lokalne startupy - wartość } \\
\text { wyuczona przez sieć neuronalną }\end{array}$ & $373,44 \mathrm{mln} \mathrm{zł}$ & $373,44 \mathrm{mln} \mathrm{zł}$ & $373,44 \mathrm{mln}$ zł & $373,44 \mathrm{mln} \mathrm{zł}$ \\
\hline $\begin{array}{c}\text { Hipotetyczna wartość inwestycji } \\
\text { w lokalne startupy - wartość } \\
\text { przeliczeniowa w oparciu } \\
\text { o założenia początkowe }\end{array}$ & $15771 \mathrm{mln}$ zł & $19050 \mathrm{mln} \mathrm{zł}$ & $22852 \mathrm{mln} \mathrm{zł}$ & $3950 \mathrm{mln} \mathrm{zł}$ \\
\hline
\end{tabular}

Źródło: opracowanie własne

\section{Podsumowanie i wnioski końcowe}

Polskie miasta, zwłaszcza te duże, wydają się być na rozdrożu rozwojowym. Z jednej strony, trendy demograficzne w skali całej Polski wskazują że jako kraj zdążamy w kierunku przeciwnym do tendencji światowej. O ile w skali świata ma miejsce postępująca urbanizacja ludności, o tyle Polska wykazuje raczej de-urbanizację. Na przestrzeni lat 1990-2017 ponad pół miliona ludzi przeszło z miast poza ich obręb. Bardziej szczegółowe badanie siedmiu dużych miast Polski - Warszawy, Krakowa, Gdańska, Wrocławia, Poznania, Łodzi i Kielc - wskazuje, iż samorządy miejskie wycofują się stopniowo z bezpośredniego inwestowania w środki trwałe, a więc także z wdrażania jakże potrzebnych nowych technologii. Z drugiej strony społeczności lokalne tych miast, bliskie stagnacji demograficznej, wykazują rosnącą skłonność do zachowań przedsiębiorczych i tworzenia nowych firm.

Zmiany społeczno-ekonomiczne w miastach można interpretowaćjako przejaw inteligencji zbiorowej, zaś do ich symulacji można zastosować sieć neuronalną jako formę sztucznej inteligencji. Tak jak równania fizyki kwantowej pozwalają wiarygodnie budować hipotezy na temat stanu materii i energii, tak sieć neuronalna pozwala sformułować mocne hipotezy na temat możliwych kierunków zmian w badanych siedmiu miastach. W artykule niniejszym klasyczne techniki ekonometryczne połączono z zastosowaniem takiej właśnie symulacji za pomocą sieci neuronalnej. Duże miasta Polski kryją w sobie spory potencjał do eksplozji demograficznej. W połączeniu z nieuchronnymi wyzwaniami technologicznymi, rodzi się potrzeba znalezienia nowych rozwiązań dla finansowania nowych technologii w miastach.

Spojrzenie na miasta, jako na inteligencje zbiorowe, skłania do pojmowania ich rozwoju także jako rozwoju inteligentnego, poprzez eksperymentowanie. Można wyobrazić sobie radykalną zmianę strategii miast $\mathrm{w}$ zakresie inwestowania w nowe technologie: zamiast inwestować bezpośrednio, miasto może działać poprzez lokalny fundusz inwestycyjny wyodrębniony z budżetu miejskiego. 
Fundusz taki mógłby wykorzystać nasilające się zachowania przedsiębiorcze lokalnych społeczności, selekcjonować najbardziej obiecujące spośród lokalnych startupów oraz inwestować w ich rozwój. Inteligentny rozwój zakłada, że zamiast jasnej i jednolitej ścieżki osiągania celów strategicznych mamy raczej ścieżkę eksperymentalnego generowania lokalnych rozwiązań, z których żadne nie musi być doskonałe. Zamiast jednego wielkiego programu rozwoju infrastruktury tworzymy warunki do rozwoju - a także i kontrolowanej upadłości - szeregu niewielkich startupów w tym obszarze (tj. przedsięwzięć infrastrukturalnych); zamiast jednej zwartej polityki energetycznej tworzymy warunki dla niewielkich, lokalnych eksperymentów z różnymi rozwiązaniami.

Wyzwaniem dla inteligentnego rozwoju jest umiejętne wyważenie kosztów eksperymentowania i związanego z tym ryzyka z jednej strony oraz korzyści z inteligentnego eksperymentowania z drugiej strony. Pojęcie ryzyka oraz metody zarządzania ryzykiem nabierają kluczowego znaczenia w takiej wizji rozwoju wspólnot lokalnych. Jakie ryzyko jesteśmy w stanie racjonalnie zaakceptować i jak nim zarządzać? Odpowiedzi można szukać w przedstawionych w artykule badaniach empirycznych. Niezależnie od przyjętych założeń, jeden trend rysuje się z całą pewnością: rozwój zachowań przedsiębiorczych. Dobrym pomysłem może być połączenie lokalnego funduszu inwestycyjnego z platformą crowdfundingową. Badania nad działaniem platform crowdfundingowych wskazuja że ich działalność może zostać z powodzeniem ukierunkowana na rozwój konkretnych technologii i produktów [Forbes, Shaefer 2017]. Zachowania inwestorów na platformach crowdfundingowych wykazują duże podobieństwo do pożądanych w tym przypadku wzorców inteligentnego rozwoju: opierają się na naśladownictwie połączonym ze skłonnością do aktywnego poszukiwania informacji [Hornuf, Schwienbacher 2018].

Idea połączenia lokalnego, miejskiego funduszu ubezpieczeniowego z lokalną platformą crowdfundinową może być rozwijana w dwóch kierunkach. Jeżeli przyjąć za bardziej prawdopodobne raczej te średnie trendy demograficzne obserwowane dotychczas a więc stagnację demograficzną miast przy nasilających się postawach przedsiębiorczych - najbardziej wskazany wydaje się model silnej konkurencji i zrównoważonego portfela przy selekcji startupów. Lokalny fundusz inwestycyjny mógłby wtedy stosować tzw. zasadę symetrii ryzyka: każdy milion złotych zainwestowany w lokalne startupy miałby swojego odpowiednika w postaci miliona złotych zainwestowanego w dużą zrównoważoną spółkę miejską (np. wodno-kanalizacyjną czy infrastrukturalną). Instrumenty finansowe funduszu przy tej strategii byłyby oparte na akcjach oraz papierach dłużnych.

Jeżeli jednak przyjąć za dobrą monetę predykcje przedstawione wcześniej przy zastosowaniu sieci neuronalnej, lokalny fundusz inwestycyjny powinien mieć plan zapasowy na wypadek eksplozji demograficznej i szybko postępującej kongestii. Wtedy można zastosować logikę ubezpieczeniową. Szybko rosnąca populacja przedsiębiorców wiąże się ze zwiększonym zagregowanym ryzykiem upadłości. Pozwala jednak również wykorzystać mechanizm znany w biznesie ubezpieczeniowym, kiedy populacja ubezpieczonych - a tym samym fundusz składek ubezpieczeniowych - rośnie szybciej niż zagregowana wartość szkód do kompensacji. Przy tym podejściu strategicznym, fundusz posługiwałby się w znacznie 
większym stopniu instrumentami finansowymi opartymi na kontrakcie asekuracyjnym, za pośrednictwem którego stawałby się subsydiarnym źródłem finansowania dla startupów w razie zaburzeń płynności. Najprostszą konstrukcją tego typu jest gwarancja kredytowa albo też znane już dzisiaj ubezpieczenia od bankructwa.

\section{Literatura}

Agrawal A., Catalini C., Goldfarb A., 2014, Some simple economics of crowdfunding, Innovation Policy and the Economy, 14, 1, s. 63-97.

Akande A., Cabra, P., Gomes P., Casteleyn S., 2019, The Lisbon ranking for smart sustainable cities in Europe, Sustainable Cities and Society, 44, s. 475-487.

Ameen R.F.M., Mourshed Monjur, Li, Haijiang, 2015, Acritical review ofenvironmental assessment tools for sustainable urban design, Environmental Impact Assessment Review, 55, s. 110-125, https://doi.org/10.1016/j.eiar.2015.07.006.

Armour J., Enriques L., 2018, The promise and perils of crowdfunding: Between corporate finance and consumer contracts, The Modern Law Review, 81, 1, s. 51-84.

Braudel F., 1992, Civilization and capitalism, 15th-18th century, vol. 2: The wheels of commerce, University of California Press.

Braudel F., 1985, Civilisation and Capitalism, vol. 1: The Structures of Everyday Life, William Collins \& Sons, London, s. 525-540.

Chand A. V. M., Anumitra V., 2018, Place Based Approach to plan for Resilient Cities: a local government perspective, Procedia Engineering, 212, s. 157-164.

Chen Z., Pan J., Wang L., Shen X., 2016, Disclosure of government financial information and the cost of local government's debt financing - Empirical evidence from provincial investment bonds for urban construction, China Journal of Accounting Research, 9, 3, s. 191-206.

De Vincenzo I., Massari G. F., Giannoccaro I., Carbone G., Grigolini P., 2018, Mimicking the collective intelligence of human groups as an optimization tool for complex problems, Chaos, Solitons \& Fractals, 110, s. 259-266.

Drucker P.F., 2012, The practice of management, Routledge.

Drucker P.F., 1986, Management: Tasks, responsibilities, practices, Truman Talley Books.

Dyr T., 2015, Konkurencyjna i zasobooszczędna mobilność w miastach, Autobusy: technika, eksploatacja, systemy transportowe, 16, s. 50-56.

Edgerton D., 2011, The shock of the old: Technology and global history since 1900, Profile Books Ltd. 
El Ghorab H. K., Shalaby H. A., 2016, Eco and Green cities as new approaches for planning and developing cities in Egypt, Alexandria Engineering Journal, 55, 1, s. 495-503.

Evans D. K., Holtemeyer B., Kosec K., 2019, Cash transfers increase trust in local government, World Development, 114, s. 138-155.

Forbes H., Schaefer D., 2017, Guidelines for successful crowdfunding, Procedia CIRP, 60, s. 398-403.

Fuentes S. F., Borreguero J. H., 2018, Institutional capacity in the accounting reform process in Spanish local governments, Revista de Contabilidad (Spanish Accounting Review), 21, 2, s. 188-195.

Garde A., 2009, Sustainable by design? Insights from U.S. LEED-ND pilot projects, Journal of the American Planning Association, 75, 4, s. 424-440.

Goovaerts P., Van Biesbroeck H., Van Tilt T., 2014, Measuring the effect and efficiency of city marketing, Procedia Economics and Finance, 12, s. 191-198.

Hornuf L., Schwienbacher A., 2018, Market mechanisms and funding dynamics in equity crowdfunding, Journal of Corporate Finance, 50, s. 556-574.

Isufaj M., 2014, Decentralization and the increased autonomy in Local Governments, Procedia-Social and Behavioral Sciences, 109, s. 459-463.

Jankowska M., 2015, Smart city jako koncepcja zrównoważonego rozwoju miasta-przykład Wiednia, Studia i Prace Wydziału Nauk Ekonomicznych i Zarządzania, 42, 2, s. 173-182.

Juhola S., 2018, Planning for a green city: The Green Factor tool, Urban Forestry \& Urban Greening, 34, s. 254-258.

Koszel M., Bartkowiak P., 2017, Typy koopetycji międzygminnej w polskich obszarach metropolitalnych, Studia Oeconomica Posnaniensia, 5, 9, s. 21-36.

Kumar A., 2016, The State of European Cities 2016: Cities leading the way to a better future, European Commission.

Kumaran D., Melo H. L., Duzel E., 2012, The emergence and representation of knowledge about social and nonsocial hierarchies, Neuron, 76, 3, s. 653-666.

Mauher M., Obersnel V., 2007, January, Intelligent City Balanced Scorecards for the City of Rijeka, In MIPRO 2007, 30th Jubilee International Convention.

Nikolić D., 2015, Practopoiesis: Or how life fosters a mind, Journal of Theoretical Biology, 373, s. 40-61.

Nowicka K., 2014, Smart City - miasto przyszłości, Gospodarka Materiałowa i Logistyka, 5, s. $1233-1238$.

Panya N., Poboon C., Phoochinda W., Teungfung R., 2018, The performance of the environmental management of local governments in Thailand, Kasetsart Journal of Social Sciences, 39, 1, s. 33-41. 
Parsons T., Shils E. A., Smelser N. J. (eds.), 1965, Toward a general theory of action: Theoretical foundations for the social sciences, Transaction publishers.

Pulvermüller F., 2013, How neurons make meaning: brain mechanisms for embodied and abstract-symbolic semantics, Trends in Cognitive Sciences, 17, 9, s. 458-470.

Rahman M. H., Chin H. C., 2013, A balanced scorecard for performance evaluation of sustainable urban transport, International Journal of Development and Sustainability, 2, 3, s. 1671-1702.

Randa F., Tangke P., 2015, Developing Accountability Model of Local Government Organization: From Managerial Accountability To Public Accountability (Naturalistic Study on Local Government Tana Toraja), Procedia-Social and Behavioral Sciences, 211, s. 665-672.

Rupeika-Apoga R., Danovi A., 2015, Availability of alternative financial resources for SMEs as a critical part of the entrepreneurial eco-system: Latvia and Italy, Procedia Economics and Finance, 33, s. 200-210.

Sałabun W., Karczmarczyk A., 2018, Using the COMET Method in the Sustainable City Transport Problem: An Empirical Study of the Electric Powered Cars, Procedia Computer Science, 126, s. 2248-2260.

Savelyev A., 2017, Contract law 2.0:'Smart'contracts as the beginning of the end of classic contract law, Information \& Communications Technology Law, 26, 2, s. 116-134.

Sedmihradská L., 2015, Budget transparency in Czech local government, Procedia Economics and Finance, 25, s. 598-606.

Sikora-Fernandez D., 2013, Koncepcja "smart city” w założeniach polityki rozwoju miasta - polska perspektywa, Acta Universitatis Lodziensis Folia Oeconomica, 290, s. 83-94.

SitziaS., ZhengJ., 2018, Group behaviour in tacitcoordination games with focal points: Anexperimental investigation (No. 17-02R), School of Economics, University of East Anglia, Norwich, UK.

Sloman A., 1993, Prospects for AI as the general science of intelligence. Prospects for artificial intelligence, 1 OS Press, Amsterdam, s. 1-10.

Smith A., 1776, An inquiry into the wealth of nations, Strahan and Cadell, London.

Staš D., Lenort R., Wicher P., Holman D., 2015, Green Transport balanced scorecard model with analytic network process support, Sustainability, 7, 11, s. 15243-15261.

Stawasz D., Sikora-Fernandez D., Turała M., 2012, Koncepcja smart city jako wyznacznik podejmowania decyzji zwiazanych z funkcjonowaniem i rozwojem miasta, Zeszyty Naukowe Uniwersytetu Szczecińskiego, 721, 29, s. 97-109.

Stradner J., Thenius R., Zahadat P., Hamann H., Crailsheim K., Schmickl T., 2013, Algorithmic requirements for swarm intelligence in differently coupled collective systems, Chaos, Solitons\&Fractals, 50, s. 100-114. 
Szymańska D., Korolko M., 2015, Inteligentne miasta: idea, koncepcje i wdrożenia, Wydawnictwo Naukowe Uniwersytetu Mikołaja Kopernika, Toruń, s. 11-65.

Tomaszewska E. K., 2015, Inteligentny system transportowy w mieście na przykładzie Białegostoku, Zeszyty Naukowe Uniwersytetu Szczecińskiego. Problemy Zarządzania, Finansów i Marketingu, 41, 2.

Toynbee J. A., 1946, Study of history, Oxford University Press,

Turchin P., 2003, Complex population dynamics: a theoretical/empirical synthesis, Monographs in Population Biology, 35, Princeton University Press.

Waśniewski K., 2017, Financial Equilibrium in the Presence of Technological Change, Journal of Economics Library, 4, 2, s. 160-171.

Waśniewski K., 2017, Settlement by energy - Can Renewable Energies Sustain Our Civilisation? International Journal of Energy and Environmental Research, 5, 3, s. 1-18.

Weber M., 1922, 1978, Economy and society, University of California Press, Berkeley.

Witkowski J., Kiba-Janiak M., 2014, The role of local governments in the development of city logistics, Procedia-Social and Behavioral Sciences, 125, s. 373-385.

Zink C. F., Tong Y., Chen Q., Bassett D. S., Stein J. L., Meyer-Lindenberg A., 2008, Know your place: neural processing of social hierarchy in humans, Neuron, 58, 2, s. 273-283.

\section{Strony internetowe}

http://www.startuphubs.eu [dostęp 12.04.2019].

https://data.worldbank.org/indicator/SP.URB.TOTL.IN.ZS [dostęp 12.04.2019].

https://databank.worldbank.org/data/reports.aspx?source=2\&series=SP.POP.TOTL\&country $=$ [dostęp 13.04.2019].

https://databank.worldbank.org/data/reports.aspx?source=2\&series=SP.URB.TOTL.IN.ZS\&country=[dostęp 13.04.2019].

https://www.urenio.org/2017/03/23/2017-global-startup-ecosystem-report/ [dostęp 28.01.2019]. https://bdl.stat.gov.pl/BDL/start [dostęp 10.04.2019].

https://www.kickstarter.com/ [dostęp 7.06.2019].

https://www.startengine.com/ [dostęp 7.06.2019].

https://polakpotrafi.pl [dostęp 7.06.2019]. 


\section{Apendyks A - dane empiryczne}

Tabela A.1.

\begin{tabular}{|c|c|c|c|c|c|}
\hline Miasto & Rok & $\begin{array}{l}\text { Wydatki } \\
\text { inwestycyjne } \\
\text { samorządu }\end{array}$ & $\begin{array}{c}\text { Wydatki samorządu } \\
\text { ogółem }\end{array}$ & Ludność & $\begin{array}{c}\text { Podmioty nowo } \\
\text { zarejestrowane na } 10 \\
\text { tys. ludności w wieku } \\
\text { produkcyjnym }\end{array}$ \\
\hline Warszawa & 2008 & 2087527 708,73 zł & 10522296406,41 zł & 1709781 & 200 \\
\hline Warszawa & 2009 & 2021638262,46 zł & 11348207 179,48 zł & 1714446 & 207 \\
\hline Warszawa & 2010 & 2583507 315,92 zł & 12100709 949,24 zł & 1700112 & 274 \\
\hline Warszawa & 2011 & $2092758006,68 \mathrm{zł}$ & 12268789 156,22 zł & 1708491 & 249 \\
\hline Warszawa & 2012 & $2122173152,84 \mathrm{zł}$ & $12612689332,53 \mathrm{zt}$ & 1715517 & 274 \\
\hline Warszawa & 2013 & $1820460201,43 \mathrm{zł}$ & $12147976239,87 \mathrm{zł}$ & 1724404 & 307 \\
\hline Warszawa & 2014 & 2351289352,77 zł & 13452190 186,67 zł & 1735442 & 303 \\
\hline Warszawa & 2015 & $1318029329,59 \mathrm{zł}$ & $12894306372,51 \mathrm{zł}$ & 1744351 & 348 \\
\hline Warszawa & 2016 & $1237774655,26 \mathrm{zl}$ & $13789826629,81 \mathrm{zł}$ & 1753977 & 364 \\
\hline Warszawa & 2017 & $1839067664,23 \mathrm{zł}$ & 15271678033,46 zł & 1764615 & 345 \\
\hline Kraków & 2008 & 622977 410,64 zł & 3155492 670,82 zł & 754624 & 200 \\
\hline Kraków & 2009 & $697372601,05 \mathrm{zł}$ & $3419539327,83 \mathrm{zl}$ & 755000 & 205 \\
\hline Kraków & 2010 & 560229655,77 zł & 3364487928,06 zł & 757740 & 241 \\
\hline Kraków & 2011 & $482718432,37 \mathrm{zł}$ & 3319300471,48 zł & 759137 & 204 \\
\hline Kraków & 2012 & 440361885,58 zł & $3488358626,44 \mathrm{zł}$ & 758334 & 230 \\
\hline Kraków & 2013 & $401241672,33 \mathrm{zł}$ & $3639799260,47 \mathrm{zł}$ & 758992 & 224 \\
\hline Kraków & 2014 & $669726014,67 \mathrm{zł}$ & 4074523802,86 zł & 761873 & 216 \\
\hline Kraków & 2015 & $578795861,67 \mathrm{zł}$ & $4213940360,37 \mathrm{zl}$ & 761069 & 248 \\
\hline Kraków & 2016 & 537436 647,52 zł & $4668153875,35 \mathrm{zł}$ & 765320 & 251 \\
\hline Kraków & 2017 & 578978208,08 zł & 5014847 757,86 zł & 767348 & 257 \\
\hline Wrocław & 2008 & 1016961590,36 zł & 3193653 477,63 zł & 632162 & 190 \\
\hline Wrocław & 2009 & $1251854361,60 \mathrm{zł}$ & 3617184890,86 zł & 632146 & 195 \\
\hline Wrocław & 2010 & 795862034,93 zł & 3284126218,76 zł & 630691 & 219 \\
\hline Wrocław & 2011 & 736008 703,97 zł & 3633852581,48 zł & 631235 & 221 \\
\hline Wrocław & 2012 & 795207825,23 zł & 3692968 497,18 zł & 631188 & 228 \\
\hline Wrocław & 2013 & 520024241,48 zł & 3476388 627,21 zł & 632067 & 237 \\
\hline Wrocław & 2014 & 583338026,40 zł & $3731334054,99 \mathrm{zf}$ & 634487 & 236 \\
\hline Wrocław & 2015 & 714782 909,91 zł & $3887757298,89 \mathrm{zł}$ & 635759 & 252 \\
\hline Wrocław & 2016 & 525394021,38 zł & 3953577 738,29 zł & 637683 & 265 \\
\hline Wrocław & 2017 & 482957 768,36 zł & 4125221 167,81 zł & 638586 & 272 \\
\hline Poznań & 2008 & 652639297,19 zł & $2340447626,46 \mathrm{zł}$ & 557264 & 210 \\
\hline Poznań & 2009 & 768994 291,60 zł & 2710241474,69 zł & 554221 & 216 \\
\hline
\end{tabular}




\begin{tabular}{|c|c|c|c|c|c|}
\hline Miasto & Rok & $\begin{array}{c}\text { Wydatki } \\
\text { inwestycyjne } \\
\text { samorządu }\end{array}$ & $\begin{array}{l}\text { Wydatki samorządu } \\
\text { ogółem }\end{array}$ & Ludność & $\begin{array}{l}\text { Podmioty nowo } \\
\text { zarejestrowane na } 10 \\
\text { tys. ludności w wieku } \\
\text { produkcyjnym }\end{array}$ \\
\hline Poznań & 2010 & 872598332,02 zł & $2946734086,50 \mathrm{zł}$ & 555614 & 238 \\
\hline Poznań & 2011 & 921983033,68 zł & $3062131499,58 \mathrm{zł}$ & 553564 & 244 \\
\hline Poznań & 2012 & 594595986,42 zł & $2854406230,73 \mathrm{zł}$ & 550742 & 255 \\
\hline Poznań & 2013 & $488769038,02 \mathrm{zł}$ & $2693726494,29 \mathrm{zł}$ & 548028 & 262 \\
\hline Poznań & 2014 & $305127689,85 \mathrm{zl}$ & $2578686270,39 \mathrm{zł}$ & 545680 & 267 \\
\hline Poznań & 2015 & $748783872,69 \mathrm{zl}$ & 3106225824,22 zł & 542348 & 283 \\
\hline Poznań & 2016 & $563940519,13 \mathrm{zf}$ & 3221867 760,44 zł & 540372 & 270 \\
\hline Poznań & 2017 & $410339198,61 \mathrm{zf}$ & $3348446194,71 \mathrm{zł}$ & 538633 & 267 \\
\hline Gdańsk & 2008 & $408179728,10 \mathrm{zl}$ & 1804777 160,97 zł & 455581 & 190 \\
\hline Gdańsk & 2009 & $407502925,92 \mathrm{zł}$ & $1977884695,20 \mathrm{zf}$ & 456591 & 196 \\
\hline Gdańsk & 2010 & $530390345,97 \mathrm{zf}$ & $2164624708,71 \mathrm{zł}$ & 460509 & 213 \\
\hline Gdańsk & 2011 & 861501031,62 zł & 2543287727,12 zł & 460517 & 195 \\
\hline Gdańsk & 2012 & 1135399 074,35 zł & $2970739641,11 \mathrm{zł}$ & 460427 & 201 \\
\hline Gdańsk & 2013 & $741872522,55 \mathrm{zł}$ & 2615173427,82 zł & 461531 & 211 \\
\hline Gdańsk & 2014 & 707999 622,12 zł & $2626810097,15 \mathrm{zł}$ & 461489 & 217 \\
\hline Gdańsk & 2015 & 538956 955,44 zł & 2534477 868,38 zł & 462249 & 236 \\
\hline Gdańsk & 2016 & 408047 507,52 zł & $2680564606,73 \mathrm{zł}$ & 463754 & 238 \\
\hline Gdańsk & 2017 & 348920864,11 zł & 2870895092,32 zł & 464254 & 255 \\
\hline Łódź & 2008 & 545407851,58 zł & 2592401503,98 zł & 747152 & 160 \\
\hline Łódź & 2009 & 685056 719,52 zł & 2913925439,86 zł & 742387 & 167 \\
\hline Łódź & 2010 & $416558685,41 \mathrm{zł}$ & 2743033 994,01 zł & 730633 & 193 \\
\hline Łódź & 2011 & $379689640,60 \mathrm{zl}$ & $3045371724,39 \mathrm{zł}$ & 725055 & 169 \\
\hline Łódź & 2012 & $508963962,27 \mathrm{zł}$ & 3322647850,62 zł & 718960 & 187 \\
\hline Łódź & 2013 & 735542 148,93 zł & $3807249715,58 \mathrm{zł}$ & 711332 & 187 \\
\hline Łódź & 2014 & 936288 667,62 zł & $3837982694,69 \mathrm{zł}$ & 706004 & 189 \\
\hline Łódź & 2015 & $1071742722,38 \mathrm{zł}$ & $3997451848,33 \mathrm{zł}$ & 700982 & 183 \\
\hline Łódź & 2016 & $548951909,05 \mathrm{zf}$ & $3840394447,41 \mathrm{zł}$ & 696503 & 186 \\
\hline Łódź & 2017 & $401346557,18 \mathrm{zł}$ & $3941746169,11 \mathrm{zł}$ & 690422 & 189 \\
\hline Kielce & 2008 & $113065669,02 \mathrm{zf}$ & $741262540,71 \mathrm{zl}$ & 205094 & 140 \\
\hline Kielce & 2009 & 165600970,62 zł & $888925286,40 \mathrm{zt}$ & 204835 & 149 \\
\hline Kielce & 2010 & $207972951,41 \mathrm{zf}$ & $982945877,43 \mathrm{zł}$ & 202450 & 182 \\
\hline Kielce & 2011 & 303651239,09 zł & 1129714 765,93 zł & 201815 & 168 \\
\hline Kielce & 2012 & 239927873,97 zł & 1094018 239,75 zł & 200938 & 168 \\
\hline Kielce & 2013 & $196474206,84 \mathrm{zf}$ & $1062831642,09 \mathrm{zl}$ & 199870 & 175 \\
\hline Kielce & 2014 & $205849375,63 \mathrm{zf}$ & $1108405006,26 \mathrm{zł}$ & 198857 & 157 \\
\hline
\end{tabular}




\begin{tabular}{|c|c|c|c|c|c|}
\hline Miasto & Rok & $\begin{array}{c}\text { Wydatki } \\
\text { inwestycyjne } \\
\text { samorządu }\end{array}$ & $\begin{array}{c}\text { Wydatki samorządu } \\
\text { ogółem }\end{array}$ & Ludność & $\begin{array}{c}\text { Podmioty nowo } \\
\text { zarejestrowane na 10 } \\
\text { tys. ludności w wieku } \\
\text { produkcyjnym }\end{array}$ \\
\hline Kielce & 2015 & $286925407,14 \mathrm{zł}$ & $1204233355,27 \mathrm{zł}$ & 198046 & 185 \\
\hline Kielce & 2016 & $122944805,55 \mathrm{zł}$ & $1150430201,46 \mathrm{zł}$ & 197704 & 176 \\
\hline Kielce & 2017 & $179223278,18 \mathrm{zł}$ & $1268520464,36 \mathrm{zł}$ & 196804 & 175 \\
\hline
\end{tabular}

Źródło: Główny Urząd Statystyczny

\section{Apendyks B - opis sieci neuronalnej zastosowanej do symulacji inteligencji zbiorowej}

Sieć neuronalna jest zbudowana z czterech warstw neuronów wirtualnych, które łącznie tworzą cztery ścieżki synaptyczne. Warstwa wejściowa składa się z dwóch neuronów. Neuron 1.1 bezpośrednio pobiera zmienne wejściowe xi w pierwszej rundzie eksperymentu, zaś $\mathrm{w}$ kolejnych rundach sumuje wartości zmiennych wejściowych $\mathrm{z}$ wartością błędu $e$, obliczonego przez neuron selekcyjny (neuron 4), zgodnie z równaniem (B.5) podanym dalej. Neuron 1.2. oblicza wartości lokalnej funkcji spójności $V\left(x_{i}\right)$ dla każdej ze zmiennych, szacowanej według równania (B.1) poniżej, gdzie $x_{i}$ to lokalna wartość zmiennej, dla której obliczana jest funkcja spójności, $\mathrm{N}$ to całkowita liczba zmiennych w tensorze objętym siecią neuronalna, $L=N-1$, zaś $x_{j}$ to każda z pozostałych zmiennych w tensorze. Lokalna funkcja spójności jest więc średnią arytmetyczną wartości xi oraz jej odległości Euklidesowych wobec pozostałych zmiennych, w danej konkretnej rundzie eksperymentalnej.

$$
V\left(x_{i}\right)=\frac{x_{i}+\sum_{j=1}^{L} \sqrt{\left(x_{i}-x_{j}\right)^{2}}}{N}
$$

Warstwa ukryta sieci składa się również z dwóch neuronów. Neuron 2.1. przypisuje wagi pseudo-losowe $w_{i}$ zmiennym wejściowym, podczas gdy neuron 2.2., który uruchamia się począwszy od drugiej rundy eksperymentalnej, przypisuje im lokalne funkcje spójności obliczone przez neuron 1.2. w poprzedniej rundzie eksperymentalnej.

W warstwie sygnału wyjściowego dwa neurony obliczają wartości dwóch różnych funkcji aktywacji. Obydwa agregują zmienne wejściowe, przetworzone przez neurony 2.1. i 2.2., do jednej wartości sygnału wejściowego $s$, jak w równaniu (B.2) poniżej, czyli jako średnią ważoną. Można powiedzieć, że neuron 2.1 przetwarza sygnały zewnętrzne - czyli eksperymentuje z różnymi kombinacjami zmiennych wejściowych - podczas gdy neuron 2.2 przetwarza sygnały wewnętrzne na temat stanu samej sieci, definiowanego za pomocą funkcji spójności $V(x)$.

$$
s=\sum_{i=1}^{N} x_{i} * w_{i} * V\left(x_{i}\right)
$$


Neuron 3.1. w warstwie sygnału wyjściowego oblicza tenże sygnał wyjściowy jako wartość funkcji sigmoidalnej $z_{g}$ według równania (B.3), podczas gdy neuron 3.2. oblicza konkurencyjny sygnał wyjściowy jako wartość $z_{h}$ funkcji tangensa hiperbolicznego według równania (B.4).

$$
\begin{aligned}
& z_{g}=\frac{1}{1+e^{-s}} \\
& z_{h}=\frac{1-e^{2 s}}{1+e^{2 s}}
\end{aligned}
$$

Ze względu na strukturę logiczną neuronów 3.1 i 3.2 zakłada się, że przedstawiają one dwa różne wzorce reakcji sieci na sygnał ze zmiennych wejściowych. Funkcja sigmoidalna neuronu 3.1 to wzorzec wygaszania silnych sygnałów, nieco jak antycykliczna polityka gospodarcza, która wygasza lokalne wstrząsy ilościowe i cenowe. Tangens hiperboliczny w neuronie 3.2 działa z kolei jak wzmacniacz lokalnych odchyleń. Można go porównać do mechanizmu stricte rynkowego, działającego nieco jak lokalna równowaga popytowo podażowa Marshalla: transmituje każde zaobserwowane odchylenie.

W warstwie selekcji neuron 4 dokonuje selekcji sygnałów wysyłanych przez neurony 3.1. i 3.2 oraz propagowania tych sygnałów jako błędów $e$ w szacowaniu zmiennej wynikowe jy. Selekcja odbywa się poprzez obliczenie średniej ważonej błędów generowanych przez neurony 3.1 i 3.2, zgodnie z równaniem (B.5) przedstawionym dalej. Wartości $z_{g}{ }^{\prime}$ oraz $z_{h}{ }^{\prime}$ to lokalne wartości pochodnych, odpowiednio dla funkcji sigmoidalnej $z_{g}$ neuronu 3.1 oraz funkcji tangensa hiperbolicznego $z_{h}$ neuronu 3.2. Współczynniki $\beta 1$ oraz $\beta 2$ mają wartości dyskretne, zadane w warunkach eksperymentu. Są to arbitralne wagi przypisane sygnałom wyjściowym neuronów 3.1 i 3.2. Odzwierciedlają one relatywne znaczenie odpowiednio funkcji wygaszania wstrząsów zewnętrznych (3.1) oraz funkcji ich wzmacniania (3.2). Mianownik $f(t)$ w równaniu (B.5) to funkcja pamięci sieci neuronalnej, czyli funkcja liczby rund eksperymentalnych $t$ już wykonanych przez sieć.

Poniższy rysunek B.1 pokazuje graficznie strukturę logiczną zastosowanej sieci neuronalnej.

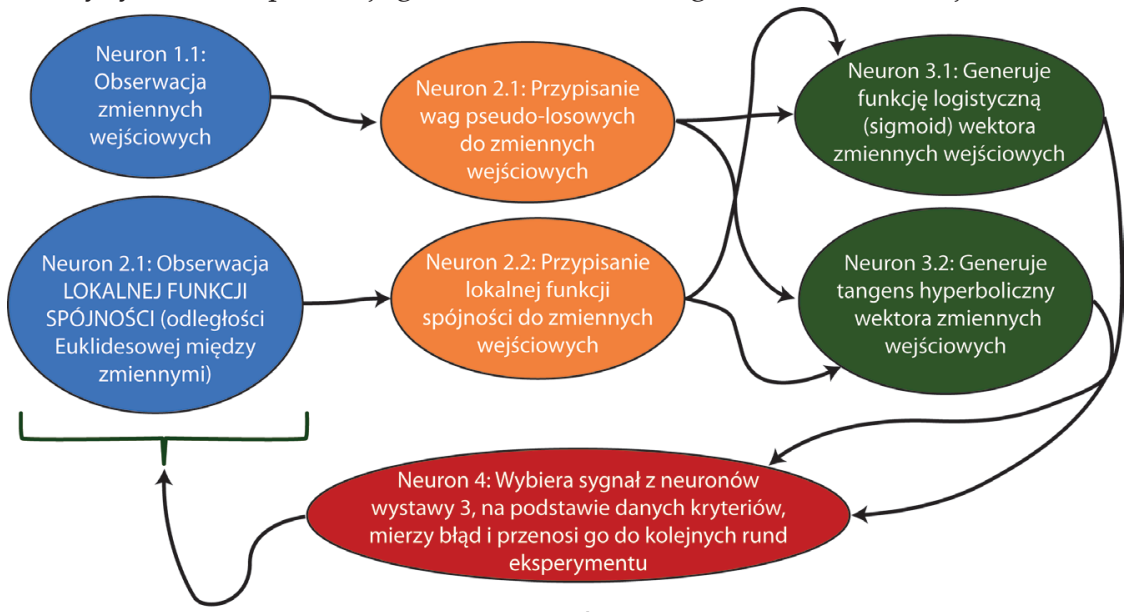

Rysunek B.1 
Sieć może okazywać dwa zasadnicze wzorce posługiwania się swoją własną pamięcią. W pierwszym wzorcu pamięć sieci jest bierna, wtedy $f(t)=1$ i błąd generowany przez każdą kolejną rundę eksperymentalną ma taką samą wagę. W drugim możliwym wzorcu sieć redukuje dysonans poznawczy: wzmacnia błędy obserwowane wcześniej i osłabia błędy obserwowane później. Odzwierciedla to zachowanie inteligentnego układu, który w miarę przyswajania nowych informacji buduje określone wyobrażenie o rzeczywistości i w miarę napływu nowych informacji o błędach ma rosnącą skłonność do ignorowania ich, jako nieistotnych. Wtedy $f(t)=t-t^{*}$, gdzie $t^{*}$ dla pierwszej rundy eksperymentalnej równa jest 0 , zaś dla kolejnych rund jest arbitralnie ustalona jako $t^{*} \geq 1$. Oczywiście, pojęcia „wcześniej” i „później” odnoszą się do liczby rund eksperymentalnych, nie do upływu rzeczywistego czasu. Im więcej wykonanych rund eksperymentu, tym „później”.

$$
e=\frac{ß_{1} *\left[\left(y-z_{g}\right) * z_{g}{ }^{\prime}\right]+ß_{2} *\left[\left(y-z_{h}\right) * z_{h}{ }^{\prime}\right]}{f(t)}
$$

\section{Apendyks C - parametry eksperymentów przeprowadzonych za pomocą sieci neuronalnej}

Wykres C.1 Średnia funkcja spójności sieci neuronalnej w Eksperymencie 1

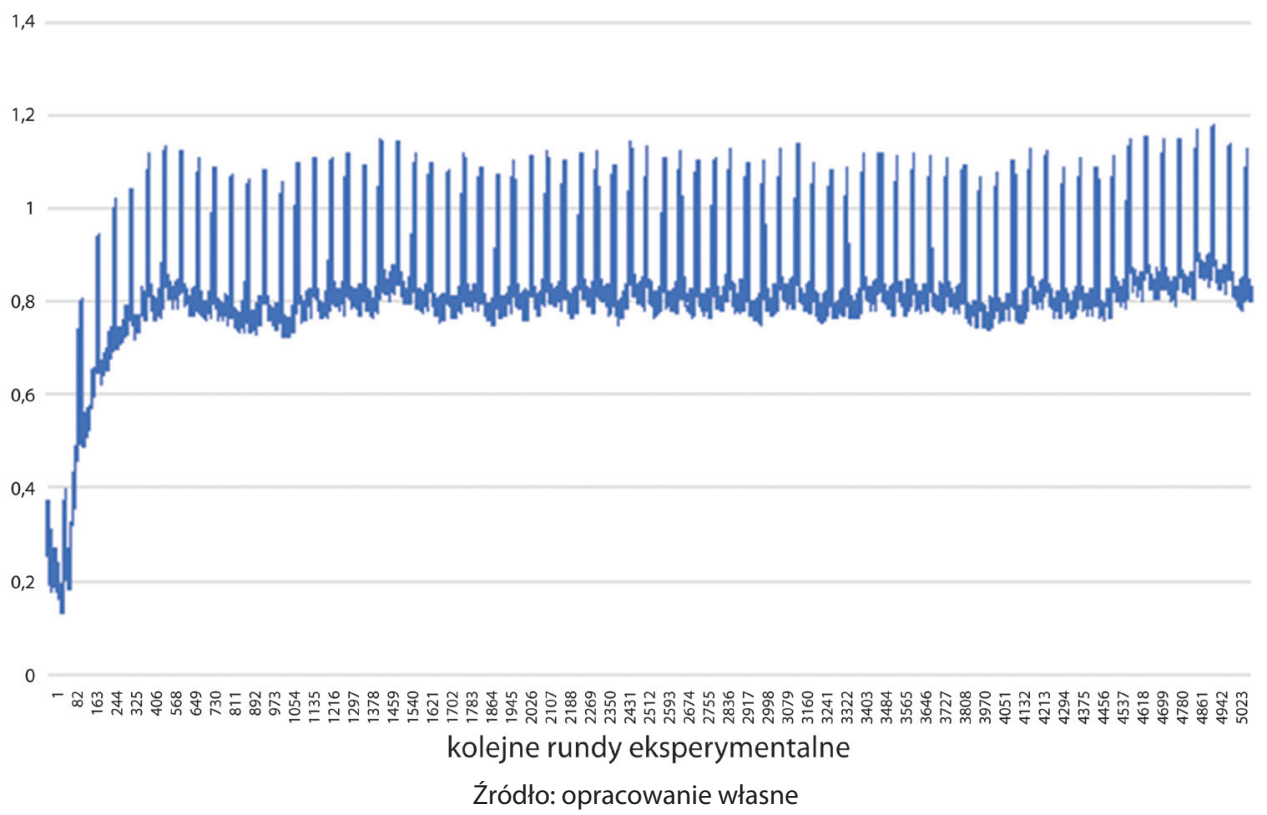


Wykres C.2 Błąd generowany przez sieć neuronalną w Eksperymencie 1

$$
0,2
$$

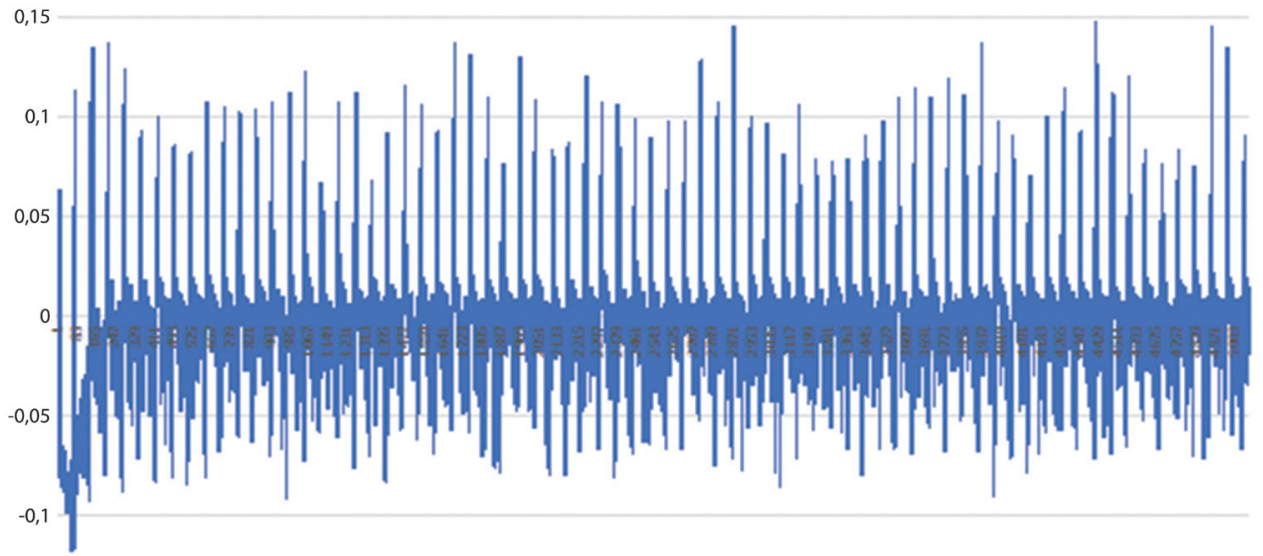
$-0,15$ kolejne rundy eksperymentalne Źródło: opracowanie własne

Wykres C.3 Średnia funkcja spójności sieci neuronalnej w Eksperymencie 2 2,5

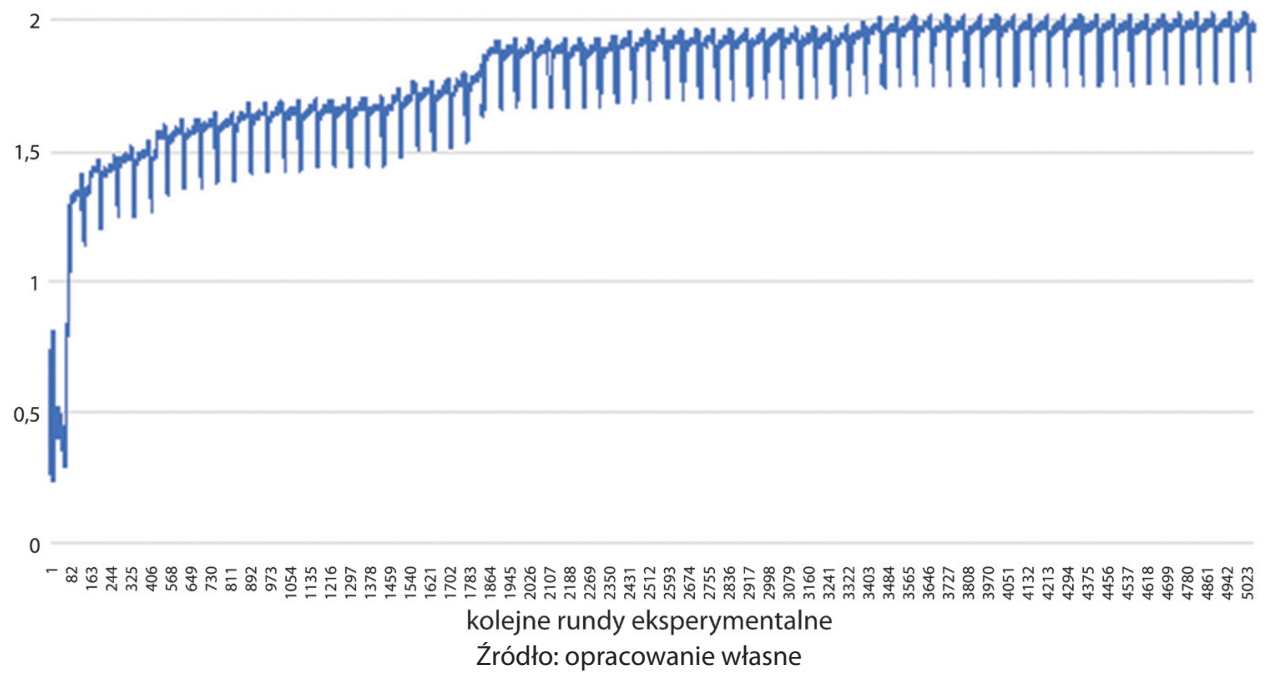


Wykres C.4 Błąd generowany przez sieć neuronalną w Eksperymencie 2

1,4

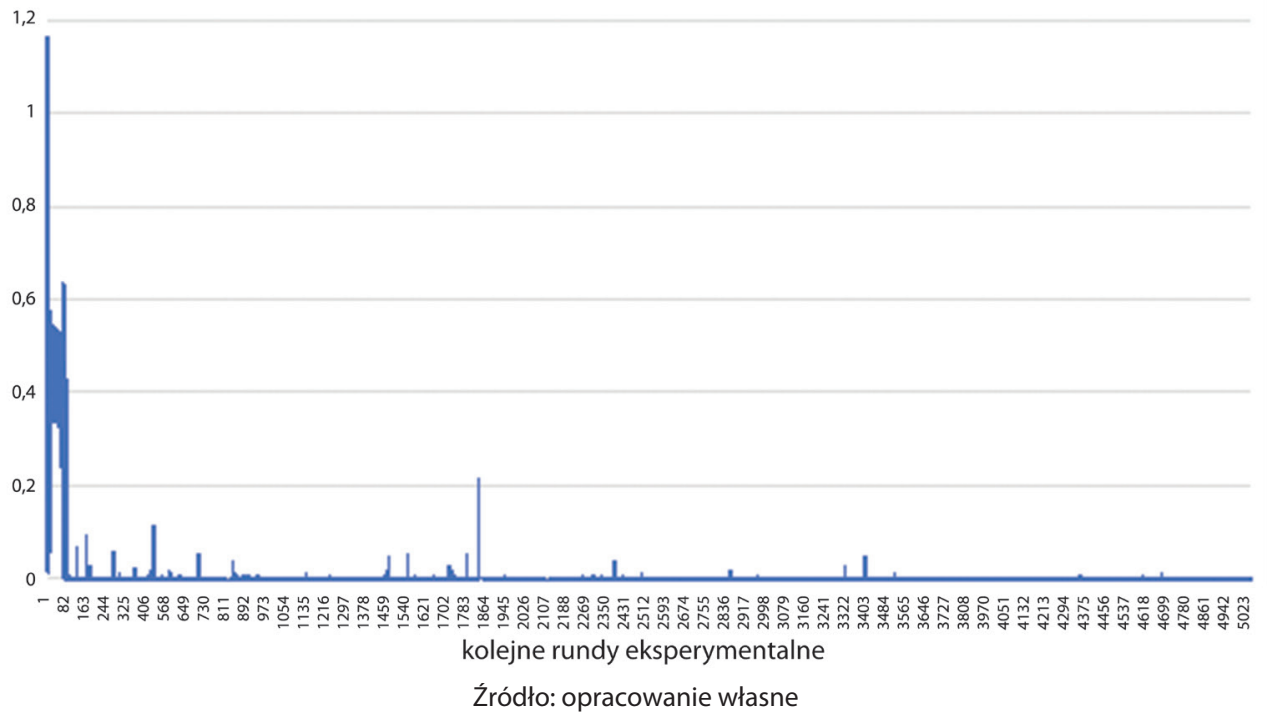

Wykres C.5 Średnia funkcja spójności sieci neuronalnej w Eksperymencie 3

2,5

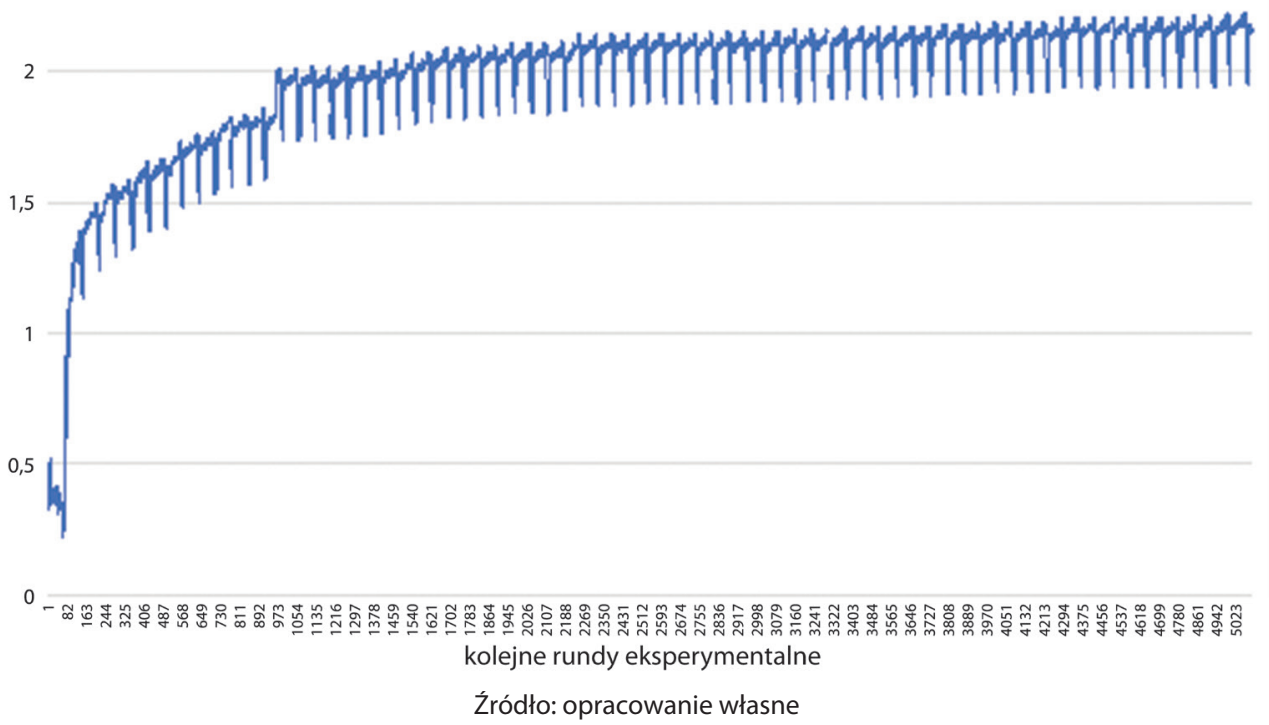


Wykres C.6 Błąd generowany przez sieć neuronalną w Eksperymencie 3

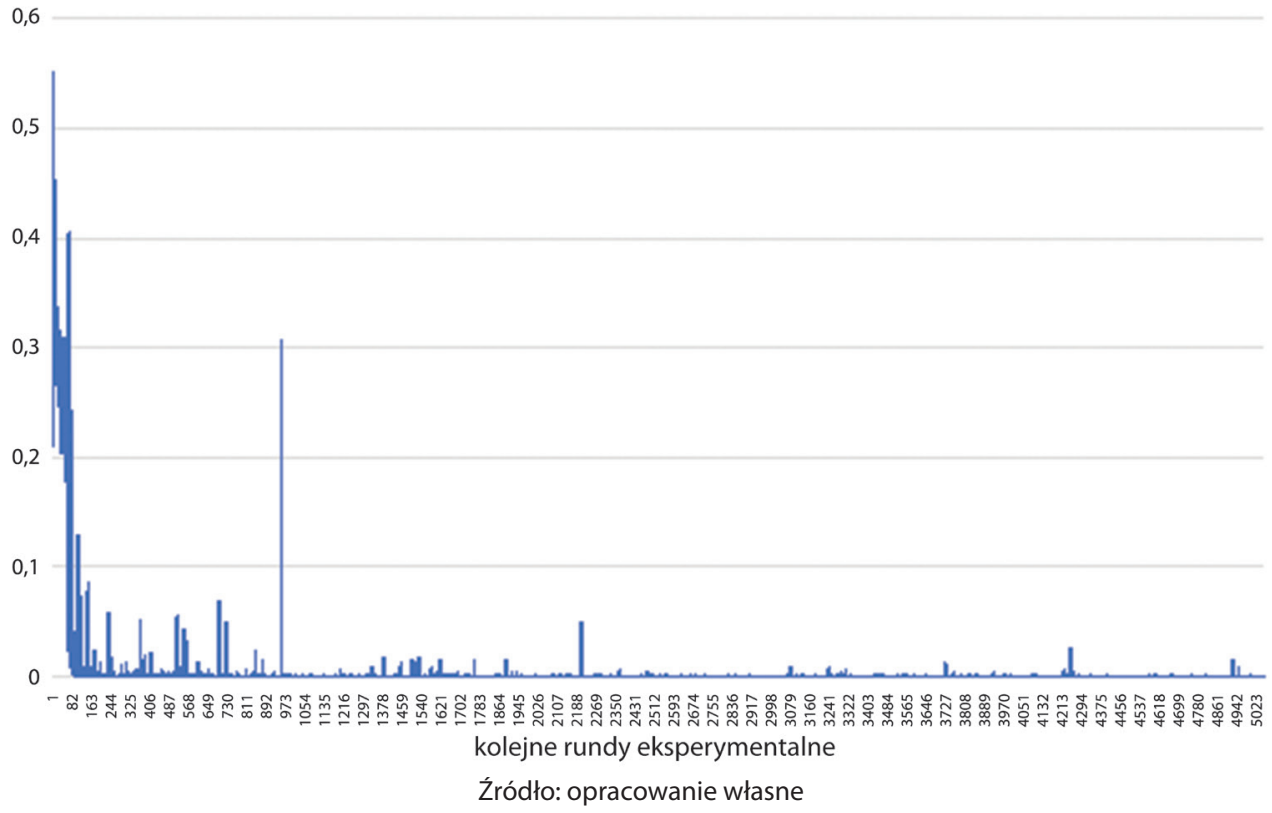

Wykres C.7 Średnia funkcja spójności sieci neuronalnej w Eksperymencie 4

1,2

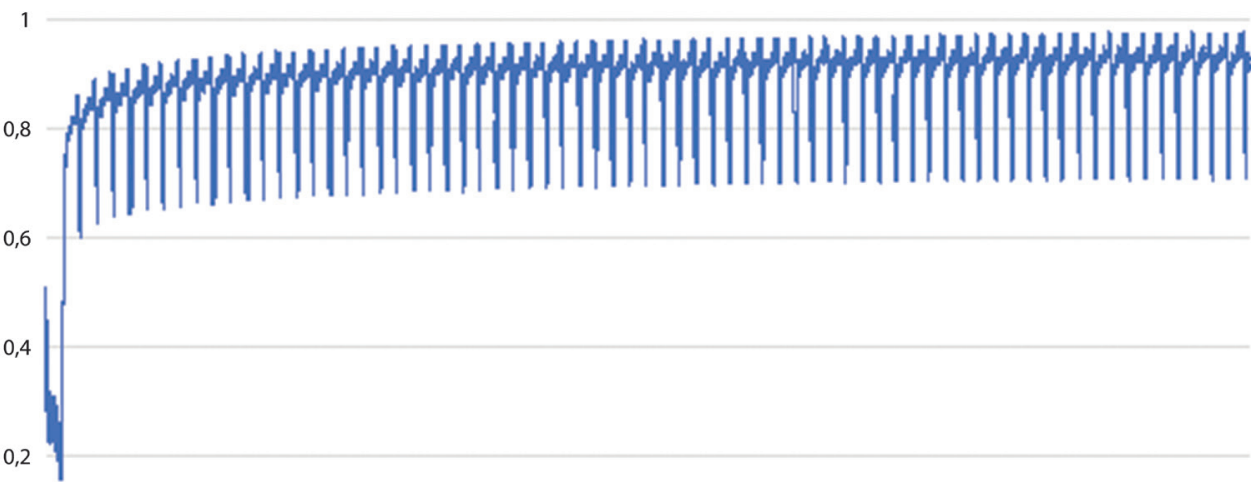

0 kolejne rundy eksperymentalne

Źródło: opracowanie własne 
64 INNOWACYJNE ROZWIĄZANIA FINANSOWE DLA INTELIGENTNEGO ROZWOJU MIAST

Krzysztof Waśniewski, Miron Maicki

Wykres C.8 Błąd generowany przez sieć neuronalną w Eksperymencie 4

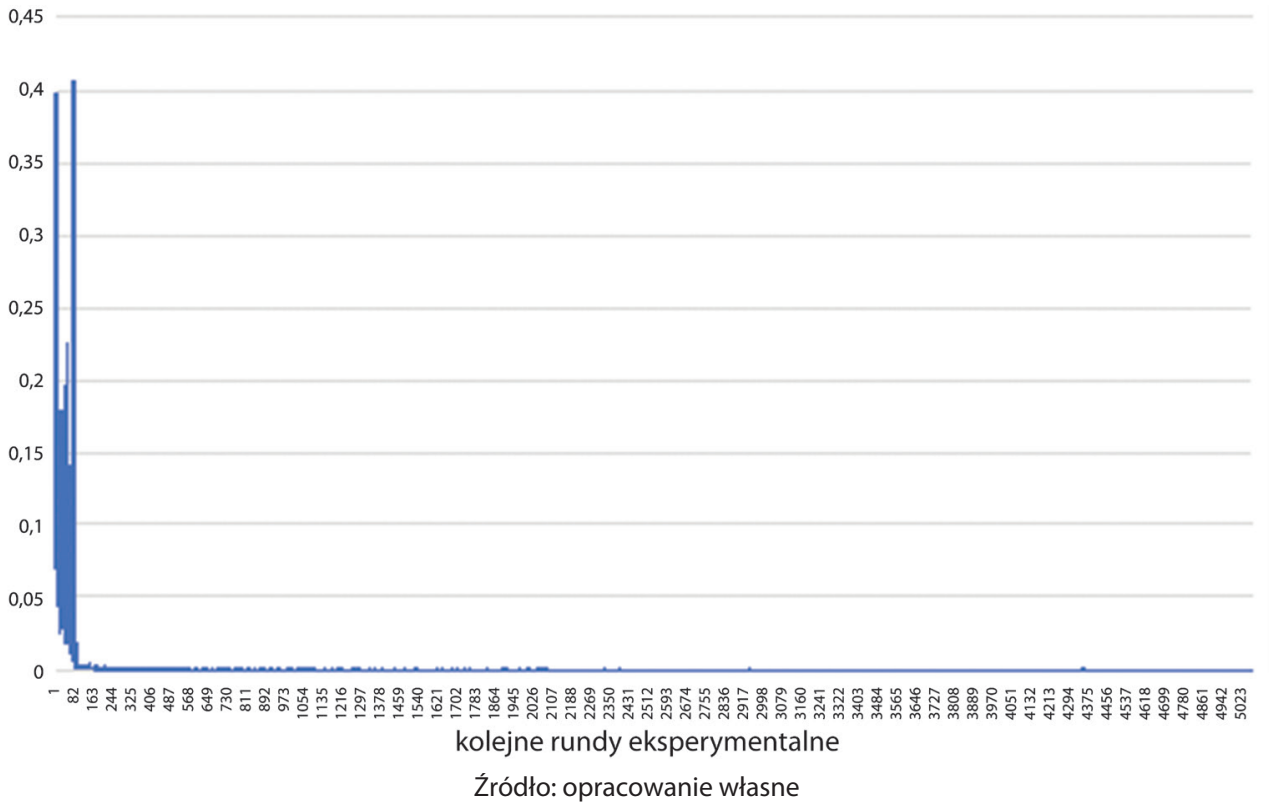




\section{Innovative financial solutions for intelligent urban development}

\section{ABSTRACT}

This article studies socio-economic changes in Polish cities in the context of technological change and the resulting challenges. Classical econometric analysis has been combined with a neural network, in order to define development patterns in seven big Polish cities:Warsaw, Cracow, Poznań, Wrocław, Gdańsk, Łodźand Kielce. The study provides mixed indications concerning futuretendencies, specifically as regards demographics.Still, two phenomena are certain: a growing tendency to start new businesses, and a decrease in the relative importance of investment outlays in municipal budgets. A simulation with a neural network indicates the possibility of a demographic explosion, despite the present stagnation, as well as a further, strong increase in the incidence of entrepreneurial behaviour. In the conclusion, this article outlines a financial solution that the observed tendencies, and combines crowdfunding with an investment fund.

Key words: Polish cities, socio-economic changes, classical econometric analysis, neural network, crowdfunding

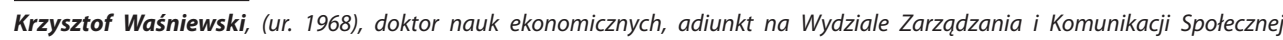
Krakowskiej Akademii im. Andrzeja Frycza-Modrzewskiego w Krakowie. Zainteresowania badawcze: zjawisko inteligencji zbiorowej, zastosowania sztucznejinteligencji, rynekenergiiiprzejściena energieodnawialne.Blognaukowy:https://discoversocialsciences.com/ email:kwasniewski@afm.edu.pl lubgoodscience@discoversocialsciences.com

Krzysztof Waśniewski, (born 1968), PhD in economics, assistant professor in the Department of Management at the Andrzej Frycz Modrzewski Krakow University (Krakow, Poland). Research interests: the phenomenon of collective intelligence, applications of artificial intelligence, the energy market and transition to renewable energy. Research blog: https://discoversocialsciences.com/ email:kwasniewski@afm.edu.plorgoodscience@discoversocialsciences.com 